\title{
Study of the Mandrillus sphinx (Cercopithecoidea) diet behaviour from the Lekedi Park (South-East, Gabon) as a valuable approach for drugs discovery
}

\author{
Gontran NSI AKOUE ${ }^{1,2 *}$, Alain SOUZA ${ }^{1}$, Richard ONANGA ${ }^{3}$, IBRAHIM ${ }^{1}$, Bertrand M'BATCHI
}

1. Laboratory of Animal Physiology: Electrophysiology-Pharmacology-URAB, University of Science and Technology of Masuku, BP 913, Franceville, Gabon.

2. Laboratory of Sciences of Life and Earth from the Ecole Normale Supérieure, BP: 17009 LibrevilleGabon

3. Unit of Medical Research and Analysis (URAM), International Medical Research Center of Franceville (CIRMF), BP: 769, Franceville-Gabon.

*Corresponding author: Tel: [+241] 07472579 or [+241] 06560363

BP: 17009 Ecole Normale Supérieure of Libreville-Gabon.

\begin{abstract}
The last decades, various research approaches have been undertaken worldwide for drug discoveries. Our study aimed to investigate medicinal plants of the Lékédi Park through a zoopharmacological and ethnopharmacological surveys on mandrills and on human population respectively from the Department of Lékoko.
\end{abstract}

Data on feeding behaviour were collected on 57 mandrills, from Lékédi Park, using a 5-min focal sampling method for 17 months. The ethnopharmacological uses were carried out on the human population using semi-structured questionnaires and scientific databases. Data were evaluated statistically by using the index of Use value (UV) and informant consensus factor (Fic).

The results showed that studied mandrills used about 147 plant species belonging to 48 botanical families. The Rubiaceae and Euphorbiaceae families were the most representative in the mandrill diet. Among plant organs eaten, some organs of plants such as bark or roots rich in non-nutritional compounds were occasionally used by mandrills, suggesting the involvement of a self-medication behavior in mandrill. Also, it appears that the plant selection would be mainly due to the availability, protein and sugar contents. Ethnopharmacological surveys show that among the 147 consumed by mandrills, $33 \%$ were used for medicinal purposes only, $41 \%$ as food and $11 \%$ were used as food and as medicine. The informant consensus factor values indicate that the medicinal plants are effective in treating certain diseases.

Thus, the study of mandrill diets behaviour would be a potential approach for the drugs discovery against bacterial and parasitic affections.

Keywords: Mandrill diet, Zoopharmacognosy, Drug discovery, Infectious diseases. 


\section{INTRODUCTION}

The discovery of new effective drugs, nowadays, represents a challenge to fight against the emergence and re-emergence of many diseases and the resistance of pathogens.

Since, infectious diseases emergence and re-emergence are a major concern for medical, veterinary, and conservation-related disciplines [1,2].

Indeed, in human populations, diseases such as malaria threaten approximately $40 \%$ of the world population with an estimate death of over 800000 per year [3]. In the same way, others pathologies as HIV/AIDS, tuberculosis, Lassa fever, Lyme disease, and cholera would represent a cause of the morbidity and the mortality in millions of people every year [4]. In addition, many neglected diseases such as ascariasis, amoebiasis and filariasis would continue to cause extensive damages to human health in Africa [5].

In order to bring out efficient therapeutic molecules in the drug market, several approaches are undertaken for the drug discovery: the chemical synthesis of bioactive molecules, the production of drugs from natural products including plants resources.

About that way, during the last decades, researchers have used different approaches in bioactive compounds research including the bio-prospection, ethnobotanical or ethnopharmacological investigations and closer, the zoopharmacological studies which involve the interactions between the wildlife and flora.

Since, the self-medication in the animal kingdom was well evidenced [6-10]. Indeed, studies on animal behavior have demonstrated that several vegetal species are ingested for health needs [1114]. In the same way, various plants are used in the realization of nests by certain species of birds. For example, Hieraaetus fasciatus would select the fragrant branches of Pinus pinaster [15-17] or for rub on their fur [18-20].

Recent studies showed that different species of wild primates such as chimpanzees (Pan troglodytes schweinfurthii, Pan troglodytes troglodytes, Pan troglodytes verus and more lately Pan troglodytes vellerosus), bonobos (Pan paniscus), and gorillas (Gorilla gorilla gorilla) occasionally use various bioactive organs of plants for prophylactic or for therapeutic purposes mainly for gastro-intestinal [21-24].

Thus, it appears that the zoopharmacognosy may constitute a very promising strategy for the human health care due to the phylogenetic proximity of humans and non-human primates (NHP). In order to study medicinal plants of Lékédi Park and to evaluate their therapeutic potential, in a public health concern, zoopharmacological and ethnopharmacological investigations were, respectively, carried out on mandrills from the la Lékédi Park and the human population from Lékoko Department.

\section{Material and methods}

\subsection{Study area}

This study realized on human and non-human primates, was conducted in the Lékédi Park located $7 \mathrm{~km}$ northeast of the village of Bakoumba $\left(1^{\circ} 47.595 \mathrm{~S}\right.$ and $\left.12^{\circ} 59.226 \mathrm{E}\right)$ and in the Lékoko Department in the province of Haut-Ogooué, Southern part of Gabon. The Department of Lékoko is divided into two districts, Miagassa (North) and Lébombi (South). The vegetation is mainly made of savannas and an alternation of rainforest-savannah [25]. 
The Lékédi is a private park, which is made of 14000 hectares of forests and divided into three fenced modules (650 ha, 1750 ha and 11600 ha, respectively). It is composed of a mosaic of savannas, grassland, and evergreen forests. Forested blocks are mainly composed of primary and secondary Marantaceae forests with patches of humid open savannas. The study area covers about 1400 ha (modules 1 and 2). It is the area of the park usually frequented by the mandrill population of survey. The module 1 is dominated by savannas, grasslands, and block of forests, which are mainly composed of secondary Marantaceae forests. The module 2 on the other hand is largely dominated by blocks of primary forests. Gabonese habitats are characterized by four different seasons: a long rainy season (February-May; during the study period: mean $\pm \mathrm{SD}$ temperatures: $23.8^{\circ} \mathrm{C} \pm 3.2^{\circ} \mathrm{C}$; total amount of rainfalls: $1256.8 \mathrm{~mm}$ ), a long dry season (JuneSeptember; $22.1^{\circ} \mathrm{C} \pm 2.6^{\circ} \mathrm{C} ; 142.2 \mathrm{~mm}$ ), a short rainy season (October-November; $23.3^{\circ} \mathrm{C} \pm 3.0^{\circ} \mathrm{C}$; $535.2 \mathrm{~mm}$ ) and a short dry season (December-January; $23.4^{\circ} \mathrm{C} \pm 2.9^{\circ} \mathrm{C} ; 312 \mathrm{~mm}$ ).

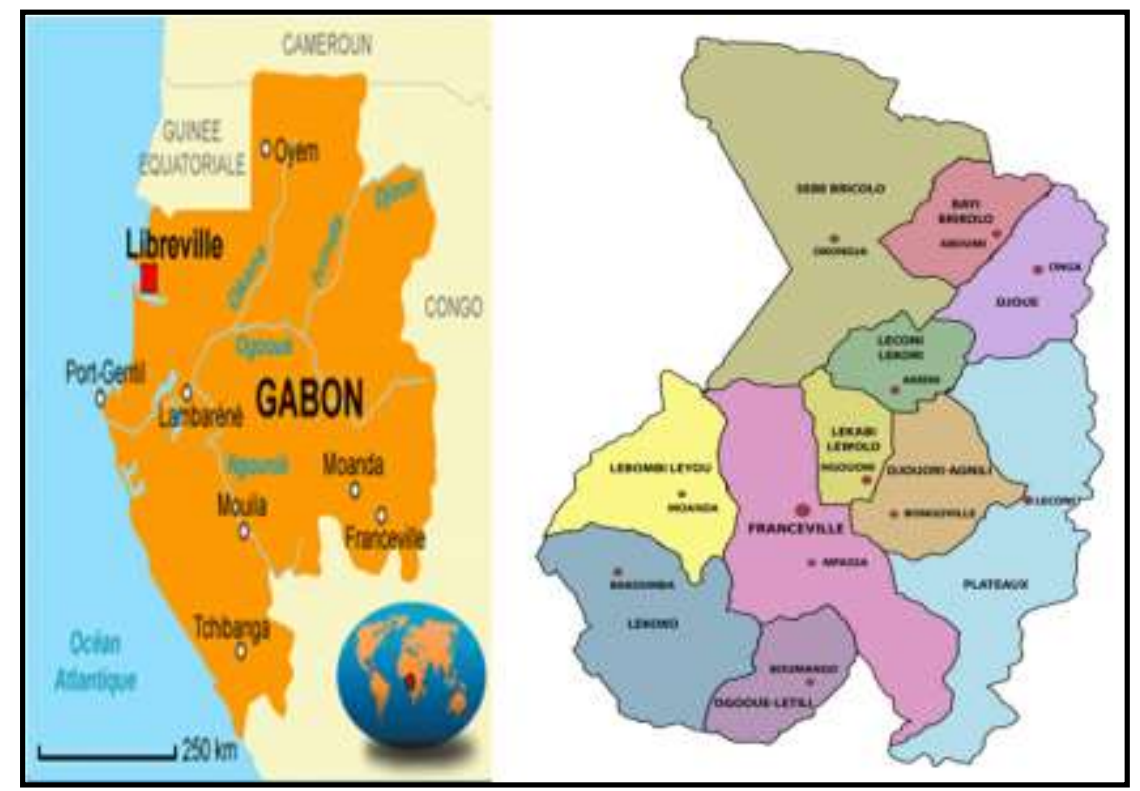

Figure 1. The localization of the study area (Lékoko Department) in Haut-Ogooué province (Gabon).

\subsection{Zoopharmacological data collection}

\subsubsection{Animal survey}

The study population of mandrills is the only habituated population of $~ 130$ free-ranging individuals living in the Lékédi Park and its vicinity. The population originated from 65 captive individuals initially housed at the CIRMF (Centre International de Recherche Médicale de Franceville, Gabon) and released in the park on two occasions (2002 and 2006; see details [26]). Daily monitoring combined with genetic analyses of the population indicates that $85 \%$ of the mandrills studied are wild-born individuals [27].

When released, mandrills can forage freely in the park and its vicinity but their diet is also supplemented with bananas and cakes about five times a week for the first few years after their release. 
However, to boost their foraging behavior, supplements of food were gradually reduced over time so that they could provide for themselves in the long run [27]. During the study period (May 2013-October 2014), the supplementation was stopped except during the capture. The group was composed of 100-120 individuals of which almost all adult individuals and all subadult males (6-9 years old) are individually known.

\subsubsection{Data collection}

Data on feeding behavior were collected on 57 individuals. We considered three classes of age. Juveniles were animals aged 1.5 years (the youngest animal in the data set) to 4 years $(\mathrm{N}=17,12$ males and 5 females). Because of a strong sexual dimorphism in this species, the pace of sexual maturity is different between sexes.We therefore considered as adolescent, females aged 4-5 years $(\mathrm{N}=3)$ and males aged 4-9 years $(\mathrm{N}=4)$. Finally, adult females were those older than 5 years $(\mathrm{N}=27)$ and males older than 9 years $(\mathrm{N}=5)$.

The study was done over a period of 17 months (May 2013-October 2014) using a 5-min focal sampling methods [28]. During focal periods, we recorded all food items (including mainly vegetal items) consumed by focal individuals and, whenever possible, the number of bites performed on each consumed food item. During the entire study period, we collected 6350 focal observations representing approximately 529 hours of data collection.

Personal observation allowed recording the different types of plants consumed by one individual. The plant samples were pressed in the field and prepared for identification. A first identification was achieved by using relevant standard literature including various region tropical floras [2934]. Final identification of plant specimens were realized from the herbaria National Herbarium of Institute of Traditional Medicine and Pharmacopoeia (IPHAMETRA) in Libreville, Gabon. These herbaceous samples were deposited in the herbarium of the Biology Department at the University of Sciences and Technique of Masuku.

\subsection{Ethnopharmacological survey}

\subsubsection{Population survey and data collection}

The local population was composed mainly of three ethnic groups (Awandji, Tsengui, and Nzébi). These three ethnic groups are originally from the North-East part of the Popular Republic of Congo in the Sangha region [35]. The Department has 12 villages and the total population is 3412 people (see: www.GeoHive - Gabon extended population statistics.htm). The majority of the population is Christian but other traditional beliefs such as Dzobi, Moughala, and Ngoyi also prevail. The different customs countered in the locality are Moanda, Chéyi, Makanda, Bavoda and Ipena [35].

Ethnobotanical information on plants consumed by the Mandrillus sphinx was collected close to 229 adult informants (98 males and 131 females) living in different villages of the Department from February to March 2015. Random interviews with groups 46 of 5 individuals were conducted. Semi-structured questionnaires were used for to collect the needed information. The questionnaire focused on the different uses of plants consumed by the mandrills, local name of the plants, foods or drugs, and the organs of the plant used. If is the plant was utilized for medicinal purposes, other information such as the pathology, preparation, methods of administration were required. Fresh plant specimens collected from the Hill were shown to 
different informants to get relevant ethnobotanical information. Interviews were carried out during busy hours and in public places such as field, yard, drawing-room, etc.

\subsubsection{Data collection from reviews}

Literature reviews on the types of plants consumed by mandrills and used in traditional medicine by local population (Table 3) were conducted. It was primarily done through the collection of abstracts and articles from: Medline (www.pubmed.gov), http://bibliovie.inist.fr, BioInfoBank (http://lib.bioinfo.pl), Elsevier (www.sciencedirect.com). We also went through books [33, 36], journals, abstracts, articles, patents, and bibliographies from Google (www.google.com ).

\subsection{Data analysis}

Ethnopharmacological data were entered in to Excel spreadsheet and summarized using descriptive statistics [37]. The Spearman rank correlation test was realized using Instat 3 software to determine whether frequency of consumption of vegetables was a significant correlation with the availability of plant species in area was used.

The use value is a quantitative method [38]. That demonstrates the relative importance of species known locally. This use value was also calculated according to the following formula:

$$
\mathrm{UV}=\mathrm{U} / \mathrm{n}
$$

UV refers to the use value of a species; $U$ to the number of citations of use per species; and $n$ to the total number of informants.

On the other hand, informant consensus factor (Fic) was employed to deduce the homogeneity of the information about a specific plant used as foods or to treat a particular category ofailments.

A high value (close to 1) indicates that the taxa (usually species) are relatively, used by a large proportion of the informants indicating a more consistent use of the medical resources. While a low value indicates that informants disagree on the taxa to be used in treatment within a category of illness. This informant consensus factor (Fic) was calculated as in the following formula [39]:

$$
\text { Fic }=\frac{(n u r-n t)}{(n u r-1)}
$$

Where $\mathrm{n}_{\mathrm{ur}}$ : number of use reports per each category and $\mathrm{n}_{\mathrm{t}}$ : number of taxa used.

\section{RESULTS}

\subsection{Investigation on plants species consumed by mandrillus}

Our study has shown that a total of 147 plants species belonging to 48 families distributed in 106 genera were eaten by 52 mandrills living in the Lékédi Park (Table 1). Based on the number of plants species consumed, the family of plants mostly consumed were Rubiaceae (9.52\%), Euphorbiaceae $(8.84 \%)$ followed by Apocynaceae $(6.12 \%)$, zingiberaceae $(5.44 \%)$. The families least consumed were Piperaceae, Pandaceae, Nymphaeaceae, Smilaceae, and Aspleniaceae with one plant species each one.

However, based on the mandrillus plant-intake (figure 2), the most consumed of plants species during the study period were Xylopia aethiopica (Annonaceae) with $13.62 \%$ followed by Croton sylvaticus (Euphorbiaceae) with $3.93 \%$, Psychotria gilletii (Rubiaceae) with $3.85 \%$, Pentaclethra macrophylla (Mimosaceae) with $2.47 \%$ and Megaphrynium macrostachum (Marantaceae) with $2.12 \%$. The least consumed plants were Plagiostyles africana 
International Journal of Advances in Scientific Research and Engineering (ijasre), Vol 5 (5), May-2019

(Euphorbiaceae) with 1.89\%, Nymphaea maculata (Nymphaeaceae) with $1.44 \%$ followed by Landolphia glabra (Apocynaceae), Parinari excelsa (Chrysobalanaceae), Agelaea rubiginosa (Connaraceae), Aframomum alboviolaceum (Zingiberaceae) with less than $1 \%$. 
International Journal of Advances in Scientific Research and Engineering (ijasre), Vol 5 (5), May-2019

Table1: Plants list consumed by the mandrill's population in Lékédi Park with different class (age and sex)

\begin{tabular}{|c|c|c|c|c|c|c|c|}
\hline Family & Scientific name and [voucher specimen no.] & Parties & $\operatorname{Ri}(\%)$ & Intake & $\mathbf{F}(\%)$ & Sex & Age \\
\hline \multirow{4}{*}{ Anacardiaceae } & Antrocaryon klaineanum Pierre [Breteler 8352] & Fruits & 99.3 & 0189 & 0.48 & All & All \\
\hline & Lannea welwitschii (Hiern) Engl. [Bourobou 508 A] & Fruits & 97.3 & 0082 & 0.21 & All & All \\
\hline & Manguifera indica L. [Bourobou 513] & Fruits & 97.3 & 0213 & 0.54 & All & All \\
\hline & Pseudospondias longifolia (Engl.) Keay [Bourobou 229] & Fruits/ Seeds & 100 & 0083 & 0.21 & All & All \\
\hline \multirow{5}{*}{ Annonaceae } & Neostenanthera myristicifolia (Oliv.) Exell [Dorr 4283] & Fruits & 98.0 & 0041 & 0.10 & All & All \\
\hline & Uvaria klaineana Engl. \& Diels [Azizet Issembé 267] & Fruits & 60.0 & 0093 & 0.24 & $\mathrm{Fe}$ & Ad \\
\hline & Uvaria scrabida Oliv [Bos 10671] & Seeds & 58.0 & 5381 & 13.62 & All & All \\
\hline & Xylopia aethiopica(Dunal) A.Rich [Azizet Issembé 226] & Seeds & 52.0 & 0118 & 0.30 & All & All \\
\hline & Xylopia staudtii Engl. \& Diels [Bois SRFG 823] & Seeds & 57.3 & 0009 & 0.02 & $\mathrm{Fe}$ & Ad \\
\hline \multirow{9}{*}{ Apocynaceae } & Landolphia breviloba J.G.M.Pers. [Breteler 6953] & Fruits & 86.7 & 0340 & 0.86 & All & All \\
\hline & Landolphia dewevrei Stapf [Breteler 8718] & Fruits & 84.0 & 0010 & 0.03 & All & All \\
\hline & Landolphia glabra (Pierre ex Stapf) Pichon [Breteler 8030] & Fruits & 94.7 & 0390 & 0.99 & All & All \\
\hline & Landolphia hirsuta (Hua) Pichon [Arends 587] & Fruits/ Leaves & 92.0 & 0036 & 0.09 & All & All \\
\hline & Landolphia incerta (K.Schum.) J.G.M. Pers. [Arends 319] & Fruits & 98.0 & 0375 & 0.95 & All & All \\
\hline & Landolphia mannii Dyer [Breteler 10731] & Fruits & 100 & 0824 & 2.09 & All & All \\
\hline & Landolphia owariensis P. Beauv. [Bourobou 404] & Fruits & 90.0 & 0040 & 0.10 & All & All \\
\hline & Landolphia sp. P.Beauv. [van Bergen 102 ] & Stems & 85.3 & 0012 & 0.03 & All & Ad/ Juv \\
\hline & Rauvolfia vomitoria Afzel. [Bernard SRFG 1628] & Stems/ Fruits & 87.3 & 0193 & 0.49 & All & All \\
\hline \multirow{5}{*}{ Aracaceae } & Elaeis guineensis Jacq. [Simons 376] & Fruits & 94.0 & 0203 & 0.51 & All & All \\
\hline & $\begin{array}{l}\text { Laccosperma laeve (G.Mann \& H.Wendl.) Wendl. [LJT } \\
\text { White 1434] }\end{array}$ & Fruits/ Stems & 46.7 & 1005 & 2.54 & All & All \\
\hline & $\begin{array}{l}\text { Laccosperma secundiflorum (P.Beauv.) Kuntze [Le Testu } \\
1658 \text { ] }\end{array}$ & Fruits & 84.7 & 0531 & 1.34 & All & All \\
\hline & Raphia vinifera P.Beauv. [van Valkenburg 2511] & Fruits & 97.3 & 0011 & 0.03 & All & All \\
\hline & Sclerosperma mannii H.Wendl. [van Valkenburg 2682] & Fruits & 96.0 & 0016 & 0.04 & $\mathrm{Ma}$ & Juvenile \\
\hline
\end{tabular}


International Journal of Advances in Scientific Research and Engineering (ijasre), Vol 5 (5), May-2019

\begin{tabular}{|c|c|c|c|c|c|c|c|}
\hline Aspleniaceae & Asplenium africanum Desv. [Sosef 1119] & Leaves & 100 & 0014 & 0.04 & $\mathrm{Ma}$ & Ado \\
\hline Balanophoraceae & Thonningia sanguinea Vahl. [Bos 10642] & Fruits & 33.3 & 0081 & 0.21 & All & Ad/ Juv \\
\hline Caesalpiniaceae & Dacryodes edulis (G.Don) H.J.Lam. [Bourobou 652] & Fruits/ Seeds & 72.0 & 0964 & 2.44 & All & All \\
\hline Chrysobalanaceae & Parinari excelsa Sabine [Breteler 14765] & Fruits/ Leaves/ Flowers and Stems & 46.0 & 0175 & 0.44 & All & All \\
\hline \multirow{2}{*}{ Commelinaceae } & Palisota ambigua (P.Beauv.) C.B.Clarke [Dibata 100] & Leaves/Stems & 57.3 & 0031 & 0.08 & All & All \\
\hline & $\begin{array}{l}\text { Palisota hirsuta (Thumb.) K.Schum. [Wilks 830] } \\
\end{array}$ & Fruits/ Leaves & 36.7 & 0060 & 0.15 & All & All \\
\hline \multirow{4}{*}{ Connaraceae } & $\begin{array}{l}\text { Agelaea rubiginosa Gilg [Wieringa 4133] } \\
\end{array}$ & Roots & 75.3 & 0564 & 1.43 & All & All \\
\hline & Cnestis corniculata Lam. [Bourobou 234] & Leaves/ Fruits & 71.3 & 0308 & 0.78 & All & All \\
\hline & Cnestis ferruginea Vahl ex DC. [Bourobou 402] & Fruits/ Leaves & 46.0 & 0028 & 0.07 & All & Ad/ Juv \\
\hline & $\begin{array}{l}\text { Cnestis sp. Sol. Ex Planch. [A.M. Louis 3309] } \\
\end{array}$ & Roots & 100 & 0045 & 0.013 & $\mathrm{Fe}$ & Ad \\
\hline Cucurbitaceae & Cogniauxia podolaena Baill. [Walters 1248] & Fruits & 100 & 0079 & 0.20 & $\mathrm{Fe}$ & $\mathrm{Ad}$ \\
\hline Cyatheaceae & Cyathea camerooniana Hook. [Bourobou 371] & Morrows & 100 & 0068 & 0.16 & All & All \\
\hline \multirow{9}{*}{ Euphorbiaceae } & Alchornea floribunda Müll.Arg [Azizet Issembé 311] & Fruits/ Leaves/ Stems & 98.7 & 0106 & 0.26 & All & All \\
\hline & Bridelia ferruginea Benth. [Bourobou 252] & Fruits & 98.7 & 0534 & 1.35 & All & All \\
\hline & $\begin{array}{l}\text { Croton mayumbensis J.Léonard [van valkenburg 2668] } \\
\end{array}$ & Fruits & 94.7 & 1554 & 3.93 & All & All \\
\hline & Croton sylvaticus Hochst. ex Krauss [Breteler 14856] & Fruits & 78.7 & 0236 & 0.61 & All & All \\
\hline & Macaranga schweinfurthii Pax [Breteler 14984] & Fruits/ Petioles & 94.7 & 0038 & 0.09 & All & All \\
\hline & Macaranga spinosa Müll.Arg. [Doumenge 148] & Fruits & 69.3 & 0840 & 2.13 & All & All \\
\hline & Maesobotrya klaineana (Pierre) J.Léonard [Jongkind 5723] & Fruits & 95.3 & 0191 & 0.48 & All & All \\
\hline & $\begin{array}{l}\text { Maesobotrya staudtii (Pax) Hutch. [van der Maesen 5768] } \\
\end{array}$ & Fruits & 95.3 & 0108 & 0.27 & All & All \\
\hline & Manniophyton fulvum Müll.Arg. [A.M. Louis 3185] & Leaves/ Stems & 99.3 & 0106 & 0.27 & All & Ad/ Juv \\
\hline
\end{tabular}

DOI: 10.31695/IJASRE.2019.33040 
International Journal of Advances in Scientific Research and Engineering (ijasre), Vol 5 (5), May-2019

\begin{tabular}{|c|c|c|c|c|c|c|c|}
\hline & Plagiostyles africana (Müll.Arg.) Prain [Azizet Issembé 223] & Fruits/ stems bark & 72.7 & 0747 & 1.89 & All & All \\
\hline & Ricinodendron heudelotii (Baill.) Heckel [A.M. Louis 2056] & Seeds & 94 & 0102 & 026 & All & All \\
\hline & Uapaca guineensis Müll.Arg. [Alers 84] & Fruits & 44.1 & 1096 & 2.78 & All & All \\
\hline & Uapaca mole Pax [Nguema Ekomo 565] & Fruits & 44.0 & 0009 & 0.02 & $\mathrm{Fe}$ & Ad \\
\hline \multirow{6}{*}{ Gramineae } & Hyparrhenia diplandra (Hack.) Stapf [Alers 72] & Leaves & 95.3 & 0204 & 0.01 & All & All \\
\hline & Jardinea gabonensis [Alers 68] & Leaves & 99.3 & 0084 & 0.21 & All & All \\
\hline & Olyra latifolia L. [Bourobou 230] & Leaves & 90.0 & 0122 & 0.31 & All & All \\
\hline & $\begin{array}{l}\text { Setaria megaphylla (Steud.) Dur. \& Schinz [Sosef 1293] } \\
\end{array}$ & Leaves & 100 & 0042 & 0.11 & $\mathrm{Fe}$ & Ad \\
\hline & Setaria $s p .[$ Sosef 1301$]$ & Leaves & 99.3 & 0008 & 0.02 & $\mathrm{Fe}$ & Ad \\
\hline & Urelytrum fasciculatum [Sosef 549] & Fruits & 98.7 & 0029 & 0.07 & All & All \\
\hline \multirow{2}{*}{ Sapotaceae } & Chrysophyllum africanum A.DC. [Bourobou 451] & Fruits & 99.3 & 0968 & 2.45 & All & All \\
\hline & Chrysophyllum lacourtianum De Wild. [Wilks 1105] & Fruits & 99.3 & 0207 & 0.52 & All & All \\
\hline Irvingiaceae & Irvingia grandifolia (Engl.) Engl. [Breteler 15429] & Fruits & 98.7 & 0438 & 1.11 & All & All \\
\hline \multirow{5}{*}{$\begin{array}{l}\text { Leguminosae- } \\
\text { Caesalpinoideae }\end{array}$} & Berlinia bracteosa Benth. [Azizet Issembé 433] & Seeds/ Flowers & 99.3 & 0009 & 0.02 & All & All \\
\hline & Berlinia confusa Hoyle [van Bergen 172] & Seeds & 84.0 & 0005 & 0.13 & All & All \\
\hline & Dialium corbisieri Staner [Ngok Banak 1092] & Leaves & 62.7 & 0428 & 1.08 & All & All \\
\hline & Dialium dinklagei Harms [Breteler 11066] & Leaves & 88.0 & 0052 & 0.13 & All & All \\
\hline & Dialium tessmannii Harms [Bois SRFG 848] & Leaves & 94.7 & 0018 & 0.05 & All & $\mathrm{Ado} / \mathrm{Ad}$ \\
\hline \multirow{5}{*}{$\begin{array}{l}\text { Leguminosae- } \\
\text { Mimosoideae }\end{array}$} & Distemonanthus benthamianus Baill. [Bernard SRFG 320] & Stems/ Leaves & 99.3 & 0554 & 1.04 & All & All \\
\hline & Parkia bicolor A.Chev. [Bourobou 369] & Seeds & 100 & 0234 & 0.59 & All & All \\
\hline & Parkia filicoidea Welw. ex Oliv. [van der Maesen 5445] & Seeds & 100 & 0001 & 0.002 & $\mathrm{Ma}$ & Ado \\
\hline & $\begin{array}{l}\text { Tetrapleura tetraptera (Schumach. \& Thonn.) Taub. } \\
\text { [Bourobou 479] }\end{array}$ & Seeds & 100 & 0002 & 0.01 & $\mathrm{Fe}$ & Ad \\
\hline & $\begin{array}{l}\text { Angylocalyx } s p \text {. Taub. [Azizet Issembé 246] } \\
\end{array}$ & Stems bark & 82.0 & 0027 & 0.07 & All & $\mathrm{Ad} / \mathrm{Juv}$ \\
\hline
\end{tabular}

www.ijasre.net

Page 76

DOI: 10.31695/IJASRE.2019.33040 
International Journal of Advances in Scientific Research and Engineering (ijasre), Vol 5 (5), May-2019

\begin{tabular}{|c|c|c|c|c|c|c|c|}
\hline & Dalhousiea africana S.Moore [Breteler 14903] & Roots & 99.3 & 0099 & 0.25 & All & All \\
\hline & Eriosema glomerata (Guill. \& Pierr.) Hook.f.[Bourobou 254] & Fruits & 95.3 & 0062 & 0.16 & All & Ad/ Juv \\
\hline \multirow{6}{*}{ Marantaceae } & Halopegia azurea (K.Schum.) K.Schum. [Ley 24] & Morrows & 62.0 & 0218 & 0.55 & All & All \\
\hline & $\begin{array}{l}\text { Haumania danckelmaniana (J.Braun \& K.Schum.) [Simons } \\
\text { 60] }\end{array}$ & Seeds/ Stems/ Roots & 68.7 & 0575 & 1.46 & All & All \\
\hline & Haumania liebrechtsiana (De Wild. \& T.Durand) [Ley 101] & Seeds/ Stems & 78.7 & 0004 & 0.01 & All & All \\
\hline & $\begin{array}{l}\text { Megaphrynium macrostachum (Benth.) Milne-Redh. } \\
\text { [Bourobou 603] }\end{array}$ & Fruits/ Stems/ Flowers/ Leaves & 52 & 0837 & 2.12 & All & All \\
\hline & $\begin{array}{l}\text { Sarcophrynium brachystachyum (Benth.) K.Schum. } \\
\text { [Wieringa 787] }\end{array}$ & Fruits/ Marrows & 72.0 & 0098 & 0.25 & All & All \\
\hline & $\begin{array}{l}\text { Trachyphrynium braunianum (K.Schum.) K.Schum. } \\
\text { [Breteler 15759] }\end{array}$ & Stems/ Seeds & 62.7 & 0195 & 0.49 & All & All \\
\hline \multirow{5}{*}{ Melastomataceae } & $\begin{array}{l}\text { Dichaetanthera africana (Hook.f.) Jacq.-Fél. [Breteler } \\
\text { 14727] }\end{array}$ & Leaves & 96.7 & 0102 & 0.26 & All & All \\
\hline & Dissotis multiflora (Sm.) Triana [Bourobou 354] & Leaves & 74.7 & 0105 & 0.27 & All & All \\
\hline & Medinilla mirabilis (Gilg) Jacq.-Fél. [A.M. Louis 3189] & Fruits & 96.7 & 0066 & 0.17 & All & Ad/ Juv \\
\hline & $\begin{array}{l}\text { Ochthocharis dicellandroides (Gilg) C.Hansen \& Wicken } \\
\text { [Wilks 2250] }\end{array}$ & Leaves & 90.0 & 0028 & 0.07 & All & All \\
\hline & Tristemma mauritianum J.F.Gmel. [Tabak 185] & Leaves/ Fruits & 86.7 & 0002 & 0.01 & $\mathrm{Fe}$ & Ad \\
\hline Meliaceae & Carapa procera DC. [Durand SRFG 1615] & Seeds & 93.3 & 0065 & 0.16 & All & Ad/ Juv \\
\hline \multirow{4}{*}{ Mimosaceae } & $\begin{array}{l}\text { Albizia gummifera J.F.Gmel.) C.A.Sm. [van der Maesen } \\
\text { 5852] }\end{array}$ & Roots & 47.3 & 0131 & 0.33 & All & All \\
\hline & $\begin{array}{l}\text { Pentaclethra eetveldeana De Wild. \& T.Durand [A.M. Louis } \\
\text { 1587] }\end{array}$ & Seeds/ Gums & 69.3 & 0975 & 2.47 & All & All \\
\hline & Pentaclethra macrophylla Benth. [Bourobou 595] & Seeds & 64.7 & 0025 & 0.06 & All & All \\
\hline & $\begin{array}{l}\text { Piptadeniastrum africanum (Hook.f.) Brenan [Azizet } \\
\text { Issembé 230] }\end{array}$ & Leaves & 80.0 & 0067 & 0.17 & All & All \\
\hline \multirow{4}{*}{ Moraceae } & Pseudoprosopis gilletii (De Wild.) Villiers [Breteler 14835] & Young leaves & 98.7 & 0263 & 0.67 & All & All \\
\hline & Ficus mucuso Ficalho [Breteler 15338] & Fruits & 98.7 & 0526 & 1.33 & All & All \\
\hline & Musanga cecropioides R.Br. ex Tedlie [Breteler 14944] & Fruits/ Leaves/ Flowers & 92.7 & 0141 & 0.36 & All & All \\
\hline & Myrianthus arboreus P.Beauv. [Jongkind 5792] & Fruits/ Leaves & 100 & 0020 & 0.06 & All & All \\
\hline
\end{tabular}


International Journal of Advances in Scientific Research and Engineering (ijasre), Vol 5 (5), May-2019

\begin{tabular}{|c|c|c|c|c|c|c|c|}
\hline Musaceae & Musa paradisiaca $\mathrm{Cv}$. & Fruits & 84.0 & 0389 & 0.23 & All & All \\
\hline \multirow{2}{*}{ Myristicaceae } & Pycnanthus angolensis (Welw.) Warb. [Bois SRFG 827] & Fruits & 99.3 & 0018 & 0.05 & All & All \\
\hline & Scyphocephalium ochocoa (Warb. [SRFG 1770] & Fruits & 99.3 & 0570 & 1.44 & All & All \\
\hline Nymphaeaceae & Nymphaea maculata Schumach. \& Thonn. [Simons 450] & Stems/ Leaves & 80.7 & 0004 & 0.01 & $\mathrm{Fe}$ & Ad \\
\hline Ohnaceae & Ochna afzelii R.Br. ex Oliv. [Sosef 647] & Fruits & 99.3 & 0015 & 0.04 & $\mathrm{Fe}$ & Ad \\
\hline Orchidaceae & $\begin{array}{l}\text { Stanhopea hernandezii (Kunth) Schltr. [Nguema Miyono } \\
\text { 1320] }\end{array}$ & Stems/ Leaves & 41.3 & 0116 & 0.29 & All & All \\
\hline Pandaceae & Microdesmis haumaniana J.Léonard [A.M. Louis 1550] & Fruits & 98.0 & 0401 & 1.02 & All & All \\
\hline \multirow{2}{*}{ Papillonaceae } & Colopogonium mисunoides Desv [Wieringa 1268] & Flowers/ Fruits & 31.5 & 0002 & 0.01 & $\mathrm{Ma}$ & Ad \\
\hline & Popowia sp. Endl. [Azizet Issembé 278] & Roots & 69.3 & 0060 & 0.15 & All & All \\
\hline Passifloraceae & Barteria fistulosa Mast. [Breteler 14663] & Fruits/ Leaves & 100 & 0130 & 0.33 & All & All \\
\hline Pentadiplandraceae & Pentadiplandra brazzeana Baill. [A.M. Louis 1962] & Fruits & 80.7 & 0035 & 0.09 & $\mathrm{Fe}$ & Ad \\
\hline Piperaceae & Piper guineensis Schumach. \& Thonn. [Jongkind 5833] & Fruits/ Leaves & 84.0 & 0234 & 0.59 & All & All \\
\hline \multirow{14}{*}{ Rubiaceae } & Craterispermum cerinanthum Hiern [Ngok Banak 267] & Leaves/ Fruits & 53.3 & 0911 & 2.31 & All & All \\
\hline & Geophila afzelii Hiern [Mboma 23] & Fruits & 59.3 & 0554 & 1.40 & All & All \\
\hline & Lasianthus batangensis K.Schum. [Bourobou 543] & Fruits/ Leaves & 90.7 & 0029 & 0.07 & All & Ado/ Ad \\
\hline & Lasianthus sp. Jack [Ngok Banak 1734] & Fruits & 52.0 & 0071 & 0.18 & All & Ad/ Juv \\
\hline & Morinda morindoides (Baker) Milne-Redh. [Bourobou 237] & Fruits & 95.3 & 0024 & 0.06 & All & Ad/ Juv \\
\hline & Mussaenda debeauxii Wernham [Doumenge 194] & Fruits & 98.0 & 0089 & 0.23 & $\mathrm{Fe}$ & Ad \\
\hline & Mussaenda soyauxii Büttner [Simons 12] & Fruits & 100 & 0006 & 0.02 & All & All \\
\hline & Nauclea latifolia Smith. [Sosef 1806$]$ & Fruits & 77.3 & 0010 & 0.003 & $\mathrm{Ma}$ & Ad \\
\hline & $\begin{array}{l}\text { Pausinystalia johimbe (K.Schum.) Pierre ex Dup. \& Beille } \\
\text { [Azizet Issembé 255] }\end{array}$ & Young leaves & 92.7 & 0722 & 1.83 & All & All \\
\hline & $\begin{array}{l}\text { Pseudosabicea milbraedii (Wernham) N.Hallé [Azizet } \\
\text { Issembé 259] }\end{array}$ & Fruits & 76.0 & 1519 & 3.85 & All & All \\
\hline & Psychotria gilletii De Wild. [Breteler 14556] & Fruits/ Flowers & 90.7 & 0389 & 0.98 & All & All \\
\hline & Psychotria stenostegia [Azizet Issembé 220] & Leaves/ Stems/ Fruits & 98.7 & 0277 & 0.70 & All & All \\
\hline & Spermacoce latifolia Aubl. [Sosef 1290] & Leaves & 58.7 & 0453 & 1.15 & All & All \\
\hline & Tricalysia cf. breteleri Robbr. [A.M. Louis 9420] & Fruits/ Young leaves & 99.3 & 0242 & 0.61 & All & All \\
\hline
\end{tabular}


International Journal of Advances in Scientific Research and Engineering (ijasre), Vol 5 (5), May-2019

\begin{tabular}{|c|c|c|c|c|c|c|c|}
\hline Sapindaceae & $\begin{array}{l}\text { Ganophyllum giganteum (A.Chev.) Hauman [Duran SRFG } \\
1442 \text { ] }\end{array}$ & Fruits & 66.0 & 0345 & 0.87 & All & All \\
\hline Smilaceae & Smilax anceps Wild. [Doumenge 150] & Fruits/ Flowers/ Young leaves/ Stems & 100 & 0009 & 0.02 & All & $\mathrm{Ad} / \mathrm{Juv}$ \\
\hline Violaceae & Rinorea cerasifolia M.Brandt [Ngok Banak 1827] & Fruits & 90.7 & 0035 & 0.09 & All & All \\
\hline \multirow{11}{*}{ Zingiberaceae } & $\begin{array}{l}\text { Aframomum alboviolaceum (Ridl.) K.Schum. [D.W. Thomas } \\
6508 \text { ] }\end{array}$ & Fruits & 71.3 & 0573 & 1.45 & All & All \\
\hline & Aframomum daniellii (Hook.f.) K.Schum [N. Hallé 3891] & Marrows/ Fruits/ Flowers/ Stems & 97 & 0078 & 0.20 & All & All \\
\hline & $\begin{array}{l}\text { Aframomum sp. K.Schum. [Nguema Miyono 1296] } \\
\end{array}$ & Fruits & 96.7 & 0016 & 0.04 & $\mathrm{Fe}$ & $\mathrm{Ad}$ \\
\hline & Costus afer Ker Gawl. [Ngok Banak 1383] & Morrows/ Flowers & 97 & 0025 & 0.06 & All & All \\
\hline & Costus sp. L. [A.M. Louis 2016] & Morrows & 84 & 1000 & 2.53 & All & All \\
\hline & Renealmia cincinnata (K.Schum.) Baker [Sosef 1216] & Fruits & 100 & 0058 & 0.1 & $\mathrm{Ma}$ & Ad \\
\hline & Renealmia macrocolea K.Schum. [Sosef 968] & Fruits & 90.7 & 0009 & 0.02 & $\mathrm{Ma}$ & Ado/ Juv \\
\hline & Indet5 & Fruits & 100 & 0.010 & 0.02 & $\mathrm{Fe}$ & $\mathrm{Ad}$ \\
\hline & Indet6 & Fruits & 100 & 0002 & 0.007 & All & $\mathrm{Ado} / \mathrm{Ad}$ \\
\hline & Indet7 & Leaves & 99.3 & 0003 & 0.07 & $\mathrm{Ma}$ & Juv \\
\hline & Indet 10 & Leaves & 96.4 & 0056 & 0.01 & All & All \\
\hline
\end{tabular}

Ado: Adolescent individual, Juv: Juvenile individual, All: all class or all sex, Fe: Female, Ma: Male; Ad: Adult individual

DOI: 10.31695/IJASRE.2019.33040 
Regarding the organs of plants consumed (Figure 2a) and used in traditional medicine, fruits were the most consumed by mandrills (42\%), followed by stem $(24 \%)$, seeds $(16 \%)$, leaves (12 $\%)$, the least consumed were roots $(3.36 \%)$, followed by flowers $(1.64 \%)$, bark $(0.25 \%)$, gum and resin $(0.75 \%)$.

However, leaves (38\%) on the other hand are mostly used for medicinal purposes, followed by barks $(36 \%)$, stems $(12 \%)$, fruits $(7 \%)$, roots $(5 \%)$, gum and resin (2\%) (Figure $2 b)$.
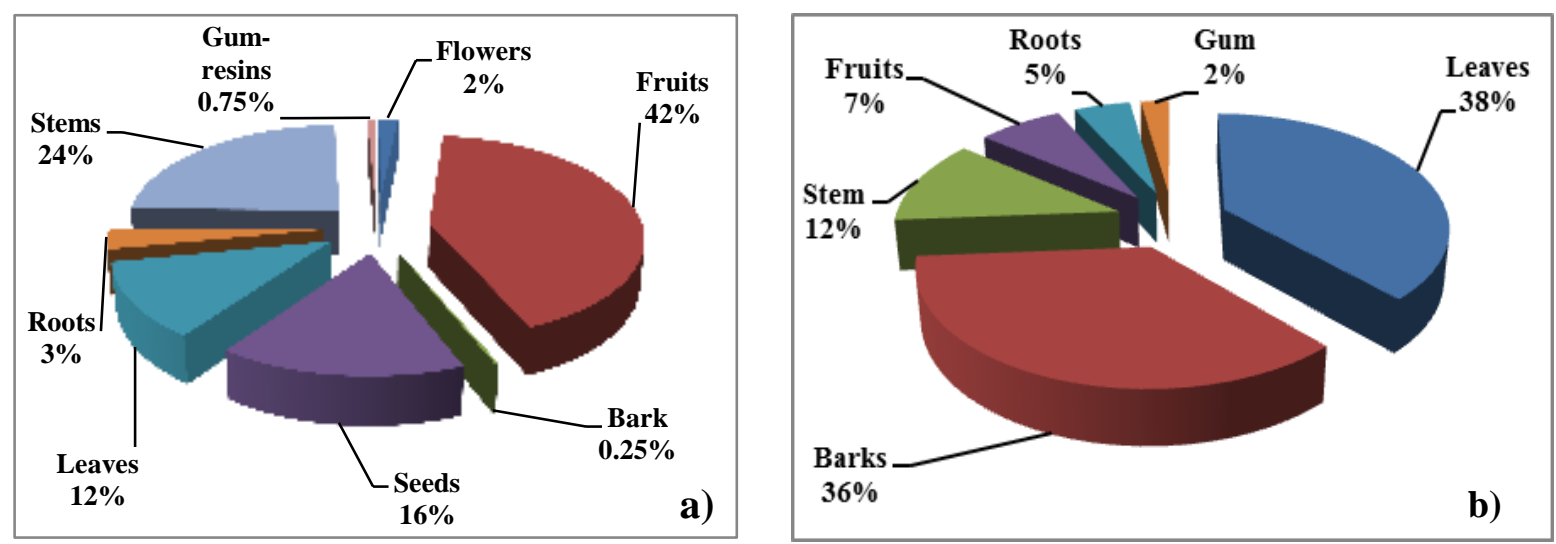

Figure 2: Contribution of plant parts in the mandrill diet (a) and in traditional medicine (b)

The figure 3 presents the correlation $(\mathrm{r}=-0.339)$ between the frequency consumption of plant species and their availability $\left(R_{i}\right)$. The result shows that the mandrills spend more time consuming vegetable species which were abundant $\left(0<R_{i}<80\right)$ in their area and that the selection of plant species by the mandrills would be made according to their availability in area.

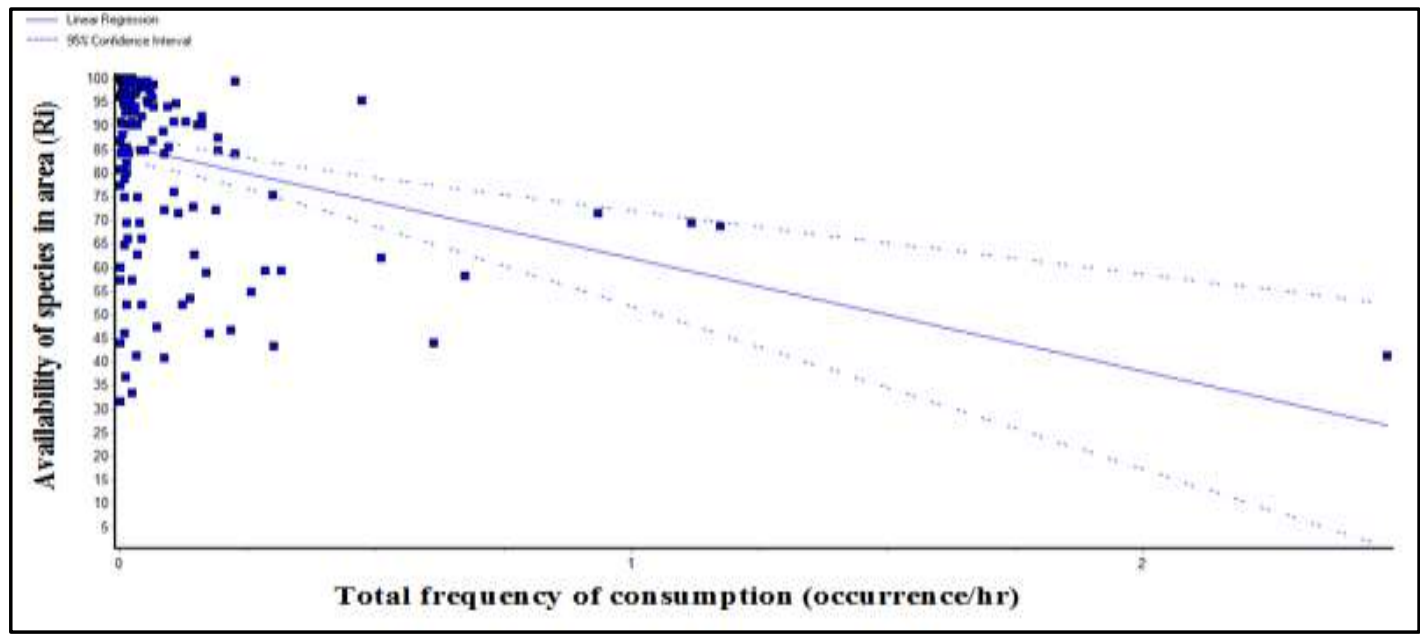

Figure 3: The correlation $(r=-0.339)$ between consumption plants and their availability The table 2 presents various plant species consumed according to the sex of the studied mandrill's population. The results show that among all plants species used by studied mandrills during study period, $11.56 \%$ vegetal species were consumed by female individuals only and $2.72 \%$ by male individuals. 
Table 2: Various plant species consumed according sex of studied mandrill's population

\begin{tabular}{|l|l|}
\hline Individual class & Plant species \\
\hline \multirow{5}{*}{ Females only } & Neostenanthera myristicifolia, Pausinystalia johimbe, Piptadeniastrum africanum \\
& Carapa procera, Urelytrum fasciculatum, Costus sp, Ochna afzelii, Uvaria \\
& scrabida, Setaria sp, Mussaenda soyauxii, Stanhopea hernandezii, \\
& Macaranga schweinfurthii, Piper guineensis, Angylocalyx sp, Cogniauxia \\
& podolaena, Cyathea camerooniana, Setaria megaphylla. \\
\hline Males only & $\begin{array}{l}\text { Popowia sp, Trachyphrynium braunianum, Bridelia ferruginea, Maesobotrya } \\
\text { staudtii }\end{array}$ \\
\hline
\end{tabular}

\subsection{Ethnopharmacological investigation on plants species consumed by the mandrillus}

The Table 2 shows ethnopharmacological data on plants consumed by the mandrillus from both the field. Among the 147 plants species, 86 plants species belonging to 31 families and 83 genera were well known by the population of the Lékoko Department. The most abundant botanical family used were Euphorbiaceae and Rubiaceae $(8.61 \%)$ followed by Leguminosae $(5.96 \%)$, Apocynaceae $(5.29 \%)$ and Zingiberaceae (4.64 \%). The least consumed family were Marantaceae (3.97 \%), Arecaceae (3.31\%), Moraceae and Commelinaceae (1.98 \%), Irvingiaceae, Burseraceae, and Cyperaceae (1.32 \%) followed by the Smilaceae, Meliaceae, Aspleniaceae, Pandaceae, Lauraceae with $1 \%$.

\subsection{Relative importance of medicinal plants consumed by the mandrills.}

According to the use values (Table 2), the highest use value reported in this study was 1 and the lowest value was 0.01 . The most commonly used vegetable species were food plants (UV=1). On the other hand, the most commonly used medicinal plants were Thonningia sanguinea (UV=0.99), Scleria boivinii (UV = 0.99), Dichaetanthera africana $(\mathrm{UV}=0.98)$, Haumania liebrechtsiana $(\mathrm{UV}=0.98)$, Haumania danckelmaniana $(\mathrm{UV}=0.95)$, Parinari excelsa $(\mathrm{UV}=$ 0.95), Costus afer (UV=0.93), Nauclea latifolia (UV=0.92), Geophila afzelii (UV=0.86) and Palisota ambigua $(\mathrm{UV}=0.76)$ which indicates their extensive use in local medicine.

The literature reviews data (Table 2) shows that some of their species have pharmacological properties. It was the case of Alchornea floribunda (antiprotozoal, antibacterial and antifungal activities), Manniophyton fulvum (antiprotozoal activities), Thonningia sanguinea (antibacterial activity against Extended-Spectrum- $\beta$-Lactamases strains), Distemonanthus benthamianus (antibacterial activity) and of Musanga cecropioides (antiprotozoal and antidiarrheal activities) were used by the mandrill population. 
International Journal of Advances in Scientific Research and Engineering (ijasre), Vol 5 (5), May-2019

Table 3: Phytochemical and ethnopharmacological of plants consumed by the mandrills and their traditional utilizations by native populations.

\begin{tabular}{|c|c|c|c|c|}
\hline Species & Local names & Traditional use & Phytochemical and pharmacology & $\mathbf{U V}$ \\
\hline Aframomum alboviolaceum & Toudoutsèrè & Food: fruits are eaten raw. & $\begin{array}{l}\text { Vitamin, calcium and Tr. Antimicrobial and anti- } \\
\text { tumor activities }[40-42] .\end{array}$ & 1 \\
\hline Aframomum cf stipulatum & Toudoumaboutou & Food: fruits are eaten raw. & & 1 \\
\hline Aframomum daniellii & Toudoumissoutou & Food: fruits are eaten raw. & $\begin{array}{l}\text { Alk, Fla and Poly. Antifungal, anthelmintic, } \\
\text { antioxydantes and antibacterial activities [43-45]. }\end{array}$ & 1 \\
\hline Albizia gummifera & Tsèlè & Wood of heating. & $\begin{array}{l}\text { Alk, Sap, Fla, and St/Tr. Antimicrobial, } \\
\text { antiplasmodial, anti- trypanosomal and antitumor } \\
\text { properties [46-50]. }\end{array}$ & 0.34 \\
\hline Alchornea floribunda & Melonlogo'o & $\begin{array}{l}\text { Food: leaves are consumed. } \\
\text { Medicinal: leaves decoction is utilized in } \\
\text { treatment of fever. }\end{array}$ & $\begin{array}{l}\mathrm{St} / \mathrm{Tr} \text {, Fla, Tan and Sap. Antiprotozoal, cytotoxic, } \\
\text { antibacterial and antifungal activities [51-53]. }\end{array}$ & $\mathbf{0 . 5 0}$ \\
\hline Antrocaryon klaineanum & Megongtsèrè & Food: Fresh fruits are consumed. & $\begin{array}{l}\text { Alk, Tan, Sap St and Re-S. Antiplasmodial } \\
\text { properties [54-57]. }\end{array}$ & 1 \\
\hline Asplenium africanum & Leninmi & Medicinal: leaves are used for bath of children & $\begin{array}{l}\text { Alk, Tan, Co, Poly and Gly. Radical scavenging } \\
\text { properties [58]. }\end{array}$ & $\mathbf{0 . 0 1}$ \\
\hline Aucoumea klaineana & Ngoumi & $\begin{array}{l}\text { Medicinal: powder of bark is consumed for } \\
\text { treatment of diarrhea. }\end{array}$ & Antimicrobial activity [59]. & 0.54 \\
\hline Barteria fistulosa & Megomena & Medicinal: bark is utilized as protection. & Gly, Alk, Fla, Tan and $\operatorname{Tr}[60,61]$. & 0.23 \\
\hline Berlinia bracteosa & Mouposse & Medicinal: gum applied for treatment of abscess. & & $\mathbf{0 . 0 1}$ \\
\hline Bridelia ferruginea & Dzandatsèrè & Medicinal: bark decoction treat the cough. & $\begin{array}{l}\text { Poly, St/ Tr, Fla, Alk, Tan, Re-S and Quinone. } \\
\text { Anti-inflammatory, antimicrobial and antioxidant } \\
\text { properties }[62,63] \text {. }\end{array}$ & $\mathbf{0 . 3 4}$ \\
\hline Carapa procera & Moudindindji & Food: seeds are consumed raw. & & $\mathbf{0 . 4 0}$ \\
\hline Chrysophyllum lacourtianum & Moubamba & Food: fresh fruits are consumed raw. & Antimicrobial activity [64]. & 1 \\
\hline Chrysophyllum africanum & Moubamba & Food: fresh fruits are consumed raw & & 1 \\
\hline Cnestis ferruginea & Unknown & Medicinal: leaves are applied on the snake bite. & $\begin{array}{l}\text { Anth, Tan, Alk, Fla and Sap. Anti-stress, } \\
\text { analgesic, antibacterial, anti-inflammatory and } \\
\text { antioxidant proprieties [65-67]. }\end{array}$ & $\mathbf{0 . 0 1}$ \\
\hline Costus afer & Mouwoussou & $\begin{array}{l}\text { Medicinal: fresh stem is eaten for treatment of } \\
\text { cough. }\end{array}$ & $\begin{array}{l}\text { Tan, Sap, Fla, St/Tr, Gly and Alk. Radical } \\
\text { scavenging [68-70]. }\end{array}$ & 0.89 \\
\hline
\end{tabular}


International Journal of Advances in Scientific Research and Engineering (ijasre), Vol 5 (5), May-2019

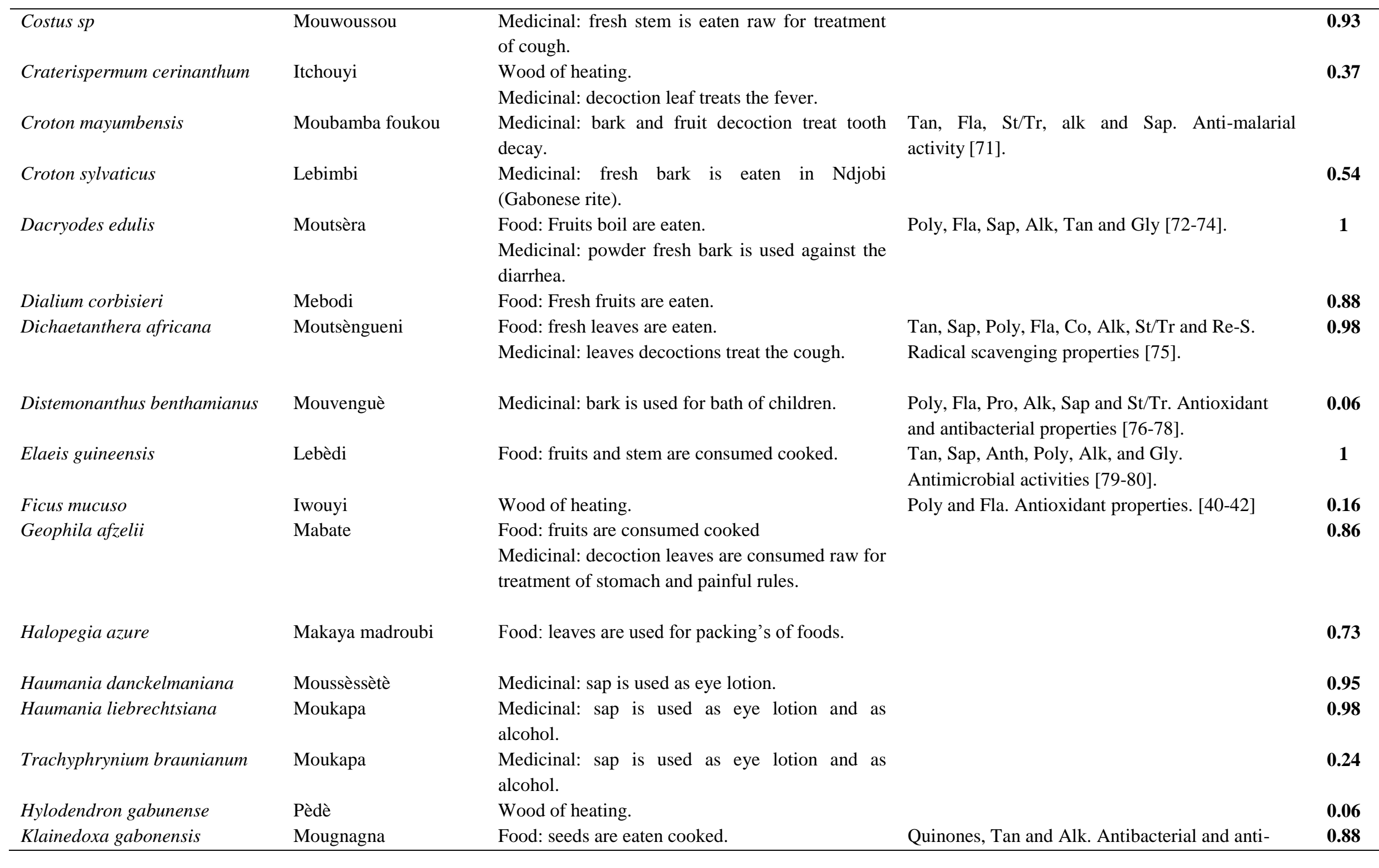

DOI: 10.31695/IJASRE.2019.33040 


\begin{tabular}{|c|c|c|c|c|}
\hline & & & tumor properties [81]. & \\
\hline Laccosperma leave & Leboulou & Food: stem is eaten cooked. & & 0.34 \\
\hline Laccosperma secundiflorum & Mokanda & Food: stem is eaten cooked. & & 1 \\
\hline Landolphia incerta & Mouke malimba & Food: fruits are eaten fresh. & & 1 \\
\hline Landolphia mannii & Mouke malimba & Food: fruits are eaten fresh. & & 0.41 \\
\hline Landolphia owariensis & Mouke malimba & Food: fruits are eaten fresh. & Tan, Poly, Fla, Alk, Sap and Gly [82-83]. & 1 \\
\hline \multirow[t]{2}{*}{ Macaranga schweinfurthii } & Moupoupourhou & Leaves are used for to transport of manioc. & & 0.56 \\
\hline & & Wood of heating. & & 0.12 \\
\hline Macaranga spinosa & Moutsètsèdè & $\begin{array}{l}\text { Medicinal: Fresh bark is consumed against the } \\
\text { diarrhea. }\end{array}$ & & \\
\hline Maesobotrya klaineana & Bekomassèssè & Food: stem is eaten cooked. & & 0.09 \\
\hline Manguifera indica & Mangue & $\begin{array}{l}\text { Food: fruits are eaten fresh and decoction of } \\
\text { leaves treat the fever. }\end{array}$ & $\begin{array}{l}\text { Alk, St/ Tr, Poly, Fla, Anth, Tan, and Quinones. } \\
\text { Anti-malarial, anti-amoebic and antimicrobial } \\
\text { properties }[84,87] \text {. }\end{array}$ & 1 \\
\hline Manniophyton fulvum & Ngnamatsarre & $\begin{array}{l}\text { Food: Leaves are used as condiment for cooking } \\
\text { of manioc leaves. }\end{array}$ & $\begin{array}{l}\text { Alk, Fla, Sap, St/ Tr, Tan and Re-S. Antiprotozoal } \\
\text { and cytotoxic activities }[88,89] .\end{array}$ & 0.90 \\
\hline Medinilla mirabilis & Bekobekongadzèli & Food: leaves are eaten cooked. & & $\mathbf{0 . 0 7}$ \\
\hline Megaphrynium macrostachyum & Makaya & Food: leaves are used for packing's of foods. & $\begin{array}{l}\text { Alk, St/ Tr, Poly, Fla, Pro, Sa and Re-S. } \\
\text { Antifungal and radical scavenging activities [ } 90 \text {, } \\
\text { 91]. }\end{array}$ & 1 \\
\hline Microdesmis haumaniana & Koutou & $\begin{array}{l}\text { Medicinal: Fresh roots are eaten for the treatment } \\
\text { of sexual weakness. }\end{array}$ & & 1 \\
\hline Morinda morindoides & Ibouéla & Medicinal: Powder of fruit treats scabies. & $\begin{array}{l}\text { Sa, Tan, Anth, St/ Tr, Pro and Gly. Antifungal } \\
\text { activities [60]. }\end{array}$ & $\mathbf{0 . 0 4}$ \\
\hline Musa paradisiaca & & Food: fruits are eaten & $\begin{array}{l}\text { Fla, Catecholamine, and Gly. Antimicrobial and } \\
\text { anti-diabetes, activities [92-95]. }\end{array}$ & 1 \\
\hline Musanga cecropioides & Moussènguè & $\begin{array}{l}\text { Medicinal: root sap is consumed for treatment of } \\
\text { cough and bark decoction treat tooth decay. }\end{array}$ & $\begin{array}{l}\text { Sa, Tan, Anth, St/Tr, Pro and Gly. Antiprotozoal, } \\
\text { antihypertensive, anti-diabetes anti-diarrhea and } \\
\text { cytotoxic activities [96-98]. }\end{array}$ & 0.56 \\
\hline Myrianthus arboreus & Mouboba & Food: Seeds are eaten fresh. & $\begin{array}{l}\text { Alk, Tan, Fla, St/ Tr and Sap. Antibacterial } \\
\text { activities [99-101]. }\end{array}$ & 1 \\
\hline Nauclea latifolia & Lebouboudji & Medicinal: decoction of bark or root is used for & Antiplasmodial, anthelmintic, antimicrobial, anti- & 0.92 \\
\hline
\end{tabular}


International Journal of Advances in Scientific Research and Engineering (ijasre), Vol 5 (5), May-2019

\begin{tabular}{|c|c|c|c|c|}
\hline & & treatment of fever. & pyretic activities [102-106]. & \\
\hline Nymphaea maculate & Itoumou chamamba & Food: dried leaves are used as salt. & & 1 \\
\hline Olyra latifolia & Viètè & Stem is used for consumed wine of palm tree. & & 0.44 \\
\hline Oncoba welwitschii & Irramba & $\begin{array}{l}\text { Fruits are used as bait of fish. The bark is utilized } \\
\text { as insecticide to collect of honey. }\end{array}$ & & 0.14 \\
\hline Palisota ambigua & Lebomboude & $\begin{array}{l}\text { Medicinal: decoction of leaves is used for } \\
\text { treatment rheumatism and stem is used for to } \\
\text { make walk children. }\end{array}$ & & 0.76 \\
\hline Palisota hirsuta & Lebomboude & $\begin{array}{l}\text { Medicinal: decoction of leaves is used for } \\
\text { treatment rheumatism. }\end{array}$ & Antimicrobial and antiviral properties [107]. & 0.55 \\
\hline Parinari excelsa & Mouguèk & $\begin{array}{l}\text { Medicinal: powder of bark treat the constipation } \\
\text { of children. }\end{array}$ & $\begin{array}{l}\text { Fla and myricetin. Antidiabetic and hypoglycemic } \\
\text { properties [108]. }\end{array}$ & 0.95 \\
\hline Parkia bicolor & Dindè & Fruits are used as bait of fish. & Tan, Alk, Gly and St. Antibacterial activity [109]. & 0.39 \\
\hline Parkia filicoidea & Tchèlè & $\begin{array}{l}\text { Medicinal: decoction of bark is consumed in } \\
\text { treatment of sexual weakness. }\end{array}$ & $\begin{array}{l}\text { Co and St/Tr. Analgesic, anti-inflammatory and } \\
\text { anti-hypertensive properties }[110,111] \text {. }\end{array}$ & $\mathbf{0 . 0 7}$ \\
\hline Paspalum scrobiculatum & Tsèrè & $\begin{array}{l}\text { Medicinal: fresh leaves applied on the body for } \\
\text { treat of dermatitis. }\end{array}$ & & 0.24 \\
\hline Pentaclethra eetveldeana & Moussame & $\begin{array}{l}\text { Medicinal: Bark put in fire is applied externally to } \\
\text { the body for treat the rheumatism. }\end{array}$ & & 0.12 \\
\hline Pentaclethra macrophylla & Moubala & $\begin{array}{l}\text { Food: Seeds are consumed cooked. } \\
\text { Medicinal: bark put in fire is applied externally to } \\
\text { the body for treat the rheumatism. }\end{array}$ & $\begin{array}{l}\text { Poly, Tan, Sap, Alk, Anth and Gly. Antimicrobial } \\
\text { activities [112-114]. }\end{array}$ & 0.81 \\
\hline Persea Americana & Ivoka & $\begin{array}{l}\text { Food: fresh fruits are consumed. } \\
\text { Medicinal: Leaves decoction treat hypertension. }\end{array}$ & $\begin{array}{l}\text { Poly, Fla, carotenoids, and vitamin (E, C). } \\
\text { Antimicrobial, analgesic anti-inflammatory, } \\
\text { hypotensive, antioxidant, anti-viral and } \\
\text { hypoglycemic properties [115-119]. }\end{array}$ & 1 \\
\hline Piper guineensis & Drougou à kète & $\begin{array}{l}\text { Food: Fruit and leaves cooked are consumed. } \\
\text { Medicinal: stem maceration treat sexual } \\
\text { weakness. }\end{array}$ & Antiprotozoal and cytotoxic activities $[120,121]$. & 1 \\
\hline Piptadeniastrum africanum & Mechinga & Medicinal: Bark put in fire is applied externally to & Alk, Fla, Gly, Sap, St/ T and, Tan. Abortive, & 0.81 \\
\hline
\end{tabular}


International Journal of Advances in Scientific Research and Engineering (ijasre), Vol 5 (5), May-2019

\begin{tabular}{|c|c|c|c|c|}
\hline & & the body for treat the rheumatism and kidney ill. & $\begin{array}{l}\text { antitumor, antimicrobial and anti-parasitic } \\
\text { activities }[53,122] .\end{array}$ & \\
\hline Plagiostyles africana & Lemvoulou & $\begin{array}{l}\text { Medicinal: fresh leaves are used as cicatrizing of } \\
\text { wound. }\end{array}$ & $\begin{array}{l}\text { Co, Fla and St/tr. Antibacterial and antifungal } \\
\text { properties [102]. }\end{array}$ & $\mathbf{0 . 0 7}$ \\
\hline Pseudospondias longifolia & Mbokili & Food: Food: fruits are eaten fresh. & Alk, Fla, Tan, Re-S and Sap [56-58]. & 0.52 \\
\hline Psychotria gilletii & Itchouyi & Wood of heating. & & 0.25 \\
\hline Pycnanthus angolensis & Lelomba & Fruits are used as bait of fish. & Anthelmintic properties [106]. & 0.18 \\
\hline Raphia vinifera & Lépika & Food: Stem is used for produce to wine palm tree. & & 1 \\
\hline Renealmia macrocolea & Dzobo'o mikoui & $\begin{array}{l}\text { Medicinal: Fresh leaves are applied on the body } \\
\text { for treatment odor corporal. }\end{array}$ & & $\mathbf{0 . 0 1}$ \\
\hline Ricinodendron heudelotii & Mouguèmbè & $\begin{array}{l}\text { Wood is used for fabrication of musical } \\
\text { instruments. }\end{array}$ & $\begin{array}{l}\text { Dinorditerpenoids, E-ferulic Acid lupeol and } \\
\text { Octacosylate. Antimicrobial activity [115-118]. }\end{array}$ & 0.09 \\
\hline Sarcophrynium brachystachyum & Makaya maldzoubou & Food: leaves are used for packing's of foods. & & 0.82 \\
\hline Scleria boivinii & Kièmè & $\begin{array}{l}\text { Medicinal: Leaves and root decoction treat sexual } \\
\text { weakness and cough. }\end{array}$ & & 0.99 \\
\hline \multirow[t]{2}{*}{ Sclerosperma mannii } & Mangua & Leaves are used for the construction of hut. & & 0.36 \\
\hline & Moutsoukou & Food: Seeds cooked are consumed. & & 0.29 \\
\hline Scyphocephalium ochocoa & & $\begin{array}{l}\text { Medicinal: Bark decoction is used for treatment } \\
\text { of cough. }\end{array}$ & & \\
\hline Selaginella myosurus & Melanguela & $\begin{array}{l}\text { Medicinal: leaves decoction is consumed for } \\
\text { treatment of gonorrhea and sexual weakness. }\end{array}$ & & 0.72 \\
\hline Setaria megaphylla & Tsèèrè & $\begin{array}{l}\text { Medicinal: leaves decoction treats the } \\
\text { constipation. }\end{array}$ & $\begin{array}{l}\text { Tan, Fla, Sap, Anth, Re-S and St/Tr. Anti- } \\
\text { diabetes and antimalarial activities [120]. }\end{array}$ & $\mathbf{0 . 3 1}$ \\
\hline Smilax anceps & Mouguila & $\begin{array}{l}\text { Food: Stem and leaves cooked are consumed. } \\
\text { Medicinal: fresh leaves are eaten treat abundance } \\
\text { menses. }\end{array}$ & $\begin{array}{l}\text { Tan, St/Tr, Anth, Sap, Re-S, Gly, Fla and Alk. } \\
\text { Antibacterial and antifungal activity [121-125]. }\end{array}$ & 1 \\
\hline Tetracera alnifolia & Moughaguela & Food: fresh water stem is consumed. & Tan, Alk, Fla, Sap, and St/Tr [78]. & 1 \\
\hline Thonningia sanguinea & Go'obe & $\begin{array}{l}\text { Medicinal: powder dried fruit is used for } \\
\text { treatment scabies. }\end{array}$ & Antimicrobial activity [59]. & 0.99 \\
\hline
\end{tabular}


International Journal of Advances in Scientific Research and Engineering (ijasre), Vol 5 (5), May-2019

Tristemma mauritianum

Bekobemassèssè

Food: fresh fruits are eaten and leaves cooked are

Uapaca guineensis

Mousèmbi

eaten.

Uapaca mole

Mousèmbi

Xylopia aethiopica

Mouyaguela foukou

Food: Fresh fruits are eaten

Alk, Fla, Co and St/Tr. Analgesic, antiulcer and

Medicinal: bark decoction treat fever anti-inflammatory properties [54, 97, 104].

Food: Fresh fruit are eaten.

Bark is used for construction of house.

Alk, Tan, Sap and St/Tr [97, 104].

Xylopia staudtii

Wood of heating.

Poly: Polyphenols, Sap: Saponins, Tan: Tannins, St/Tr: Sterols and Triterpenes, Alk: Alkaloids, Fla: Flavonoids, Re-S: Reducing Sugar, Gly: Glycosides, Anth: Anthraquinones, Co:

Coumarins, Pro: Proanthocyanidins. 
The Figure 3 shows the uses of vegetal species by native population. Among 86 plant species known, $33 \%$ were used for medicinal purposes, $41 \%$ enter in their diets and $11 \%$ of the plant species were used for food and $15 \%$ for buildings and others.

Figures 4 and 5 show various use of medicinal plants used by native people. Regarding the parts of plants used, leaves were the most used (38\%) followed by stem barks (36\%), stem (12\%) and roots $(5 \%)$.

Concerning the mode of preparation, the results (figure 7) on the medicinal use of the plants show that preparation methods most utilized by local population include the decoction (36\%), Raw (35\%) followed by powdering of the plants (12\%).

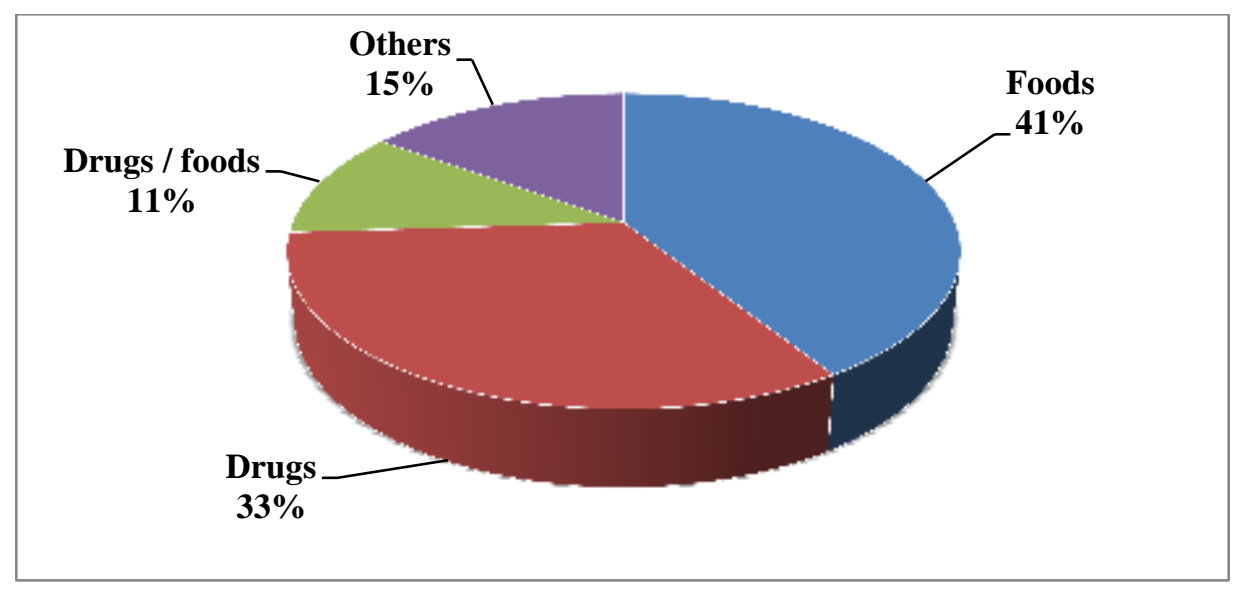

Figure 4: Traditional use of mandrill plant foods by native population.

The informant consensus factor (Fic) used to identify the ethnopharmacological importance of the collected plant species is shown in the Table 4. The results show that categories with the highest degree of consensus from informants were abscess (1), hypertension (1) and Stomach (1) followed foods, fever/malaria, diarrhea, wounds, constipation and sexual weakness with 0.99 each one. Only the pains (0.50) and thoothake (0.69) categories have shown small informant consensus factor.

Tableau 4: Category of ailments and their informant consensus factor (Fic).

\begin{tabular}{lrrr}
\hline Traditional uses & Taxons & Use reports & Fic \\
\hline Foods & 35 & 3546 & 0,99 \\
Fever/malaria & 4 & 435 & 0,99 \\
Diarrhea & 2 & 315 & 0,99 \\
Pain & 7 & 13 & 0,50 \\
Wounds & 4 & 417 & 0,99 \\
Toothake & 5 & 14 & 0,69 \\
Constipation & 2 & 230 & 0,99 \\
Abscess & 1 & 15 & 1 \\
Hypertension & 1 & 66 & 1 \\
\hline
\end{tabular}


International Journal of Advances in Scientific Research and Engineering (ijasre), Vol 5 (5), May-2019

\begin{tabular}{lrrr}
\hline Cough & 7 & 512 & 0,98 \\
Sexual weakness & 4 & 327 & 0,99 \\
Stomach & 1 & 44 & 1 \\
\hline
\end{tabular}

The figure 5 shows the various consumption modes mandill foods by department population. The results show that mandrill food plants were mainly consumed cooked and raw. Others consumption forms such as decoction, powder (figure 6) were also used. Among these modes of consumption of mandrill food plants by the native people, the cooking (43\%) and raw consumption $(27 \%)$ was the most used by the Department population.

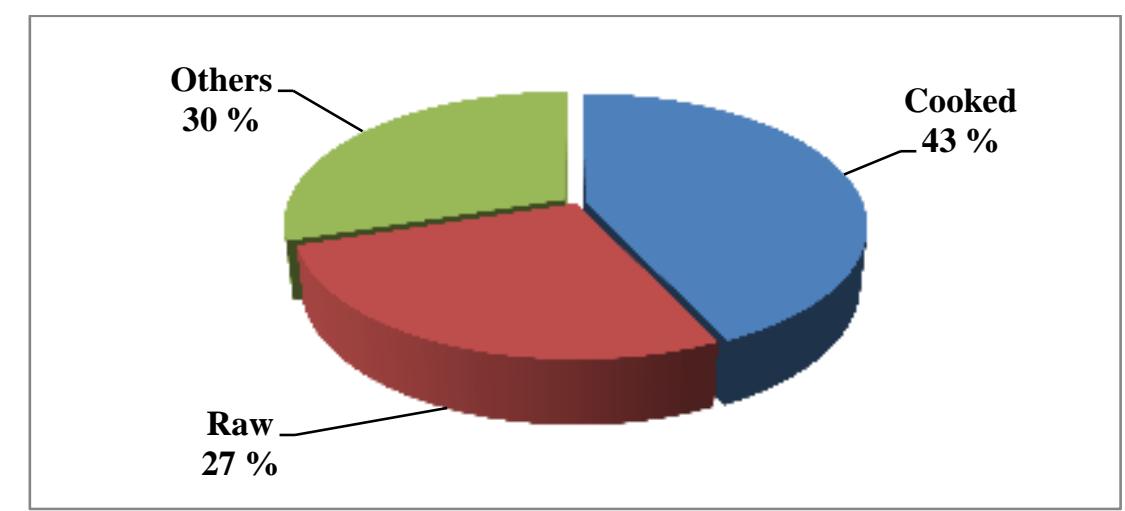

Figure 5: Various traditional methods of preparation of plant foods.

\subsection{Mode of preparation of drugs and their utilizations in traditional medicine.}

The native people of Lékoko Department were recorded to make medicinal preparations using wild plants for curative purposes via simple methods such as decoction, powder, raw, fumigation, friction, and bath. The plant species used by mandrills are used by native population in the treatment of various affections (Tbleau 2). Among plant parts used in the treatement of pathologies in traditional medecin, some also consumed by the mandrills. It is the cas of leaves of Alchornea floribunda and Craterispermum cerinanthum which are used for treat the malaria or ferver, the marrow of Costus afer and leaves of Scleria boivinii and of Dichaetanthera africana are used in the treatement of cough and the stems of Scleria boivinii are used in the treatment genital tract diseases (Table 2). 


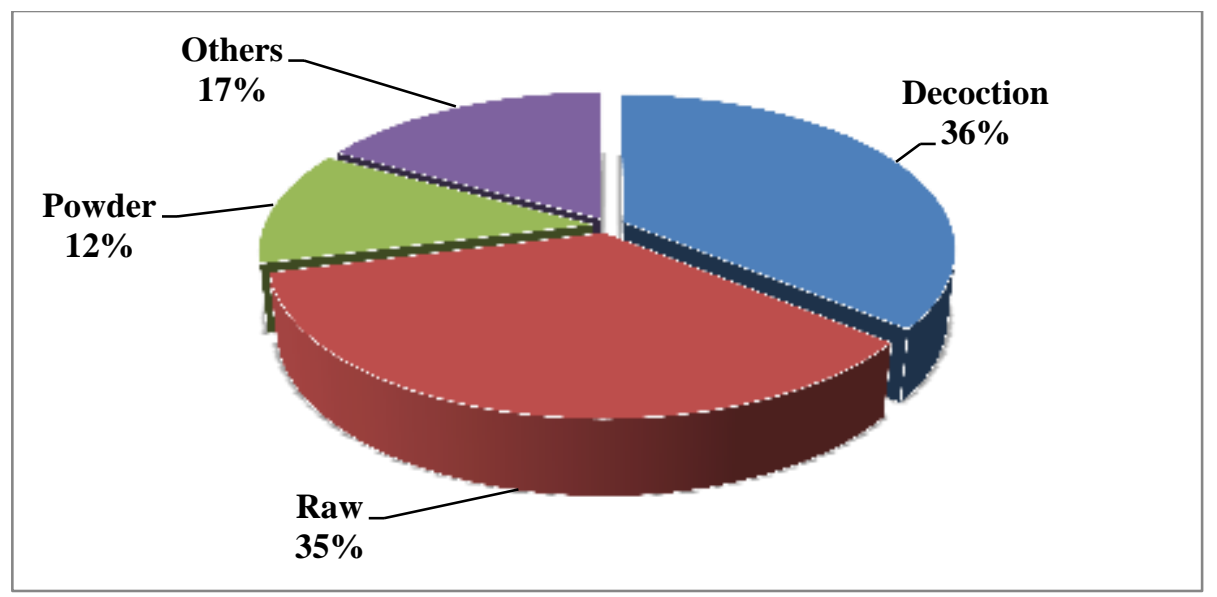

Figure 7: Various methods of preparation of remedies in traditional medicine

\section{DISCUSSION}

The present work performed on the mandrill diet at the Lékédi Park, allowed us to record 147 plants species belonging to 47 families.

Based on the number of plant species consumed per family, the results revealed that Rubiaceae and Euphorbiaceae were the most represented families, with 14 species followed by Apocynaceae and Zingiberaceae with 8 species. Among the 48 botanical families, 17 were less represented in diet Mandrillus sphinx as the case of Dilleniaceae, Sapindaceae, Flacourtiaceae, Cesalpiniaceae, Piperaceae, Nymphaeaceae, Passifloraceae, Smilaceae, with one plant species for each family (Table 1).

However, based on the food intake, the botanical family of Annonaceae (intake $=6738$ ) was the most consumed followed by Euphorbiaceae (intake = 6083), Rubiaceae (intake = 5279), Marantaceae (intake $=1794)$ and Mimosaceae (intake $=1526)$.

Despite the small representativeness in mandrill diet and their rarity in area, some families count also among the most consumed plants. It was the case of Cesalpiniaceae (intake $=964$ ) and Nymphaeaceae (intake $=570$ ). Examination of plant parts selected by mandrills, show that fruits, leaves, and stems were consumed (Table 1).

The strong representativeness of botanical families in the mandrill diet was somehow expected, since the mandrills are among the dominant fruit-eating primates [123-125] and that vegetables belonging to these different botanical families would be the most representatives in the area with the largest number of fruit plants. Indeed, more than $50 \%$ of these plants species are fruit plants. These observations on the predominance of fruits in mandrills' diet are in accordance to those reported by Petroni (2016) on Brachyteles which would have fruits as a main food source explained by the existence of higher number of fruits plants in the area (Strier, 1986).

Regarding specifically the eating-plants selection by non-human primates, several studies showed that, for diet purposes, the plants selection by these animals is determined by many factors: availability, nutrient content, non-nutritional factors such as self-medication [13, 126128]. 
In this study, the great consumption of the most representative plant species may be firstly related to their availability in the study area, since a correlation was shown between availability $\left(\mathrm{R}_{\mathrm{i}}\right)$ and the total frequency of consumption (occurrence/hr).

When we observed specifically organs of some plant species used like Chrysophyllum africanum, Myrianthus arboreus, Landolphia hirsuta and Pentaclethra macrophylla, the fruits, the leaves, and the seeds were abundantly consumed suggesting that, in addition to availability, the nutrients content may determine also the choice of plant in mandrill diet.

Since, the fruits, the leaves and the seeds are known to be a good source of carbohydrates and protein [129-132] and that the leaves of Myrianthus arboreus and Landolphia hirsuta and the seeds of Pentaclethra macrophylla consumed by Mandrillus sphinx would represent an abundant source of food proteins and are considered as a good diet protein supplements [133-135].

Our results are in phase with the works of some authors, which have shown that carbohydrates and proteins would determine the choice of food plants in animals [136-138].

Though our study did not establish a direct correlation between mineral content and the plant selection by mandrills as reported by some authors $[139,140]$ but, some mandrill diet behaviours observed may suggest that mineral content would be involved in the selection of some vegetables by mandrills.

Indeed, observations have shown that the petioles of Musanga cecropioides and the stems of Rhynchospora corymbosa are consumed by chimpanzees and lowland gorillas for their minerals content $[127,138,141]$ and these two vegetal species were also consumed by mandrills.

It is reported that minerals such as phosphorous $(\mathrm{P})$, calcium $(\mathrm{Ca})$, magnesium $(\mathrm{Mg})$, iodine $(\mathrm{I})$, manganese $(\mathrm{Mn})$, copper $(\mathrm{Cu})$, selenium $(\mathrm{Se})$, and zinc $(\mathrm{Zn})$ are involved in successful reproductive processes and that the calcium is involved in the growth, animal reproduction and the sperm capacitation $[142,143]$.

The selection of some plant species such as Setaria megaphylla, Urelytrum fasciculatum, and Uvaria scrabida by female mandrills only, Asplenium africanum and Thonningia sanguinea by juvenile and adolescent mandrills might be explained by their mineral content, which helps fulfill their physiological needs of growth and reproduction.

Indeed, ethnobotanical studies on pygmy populations from Gabon have reported that Asplenium africanum species were used to stimulate the growth of children [33]

The evidence of self-medication is well known in the animal kingdom through some animal diet behaviors [14, 144, 145]: the use by animals of particular plants that are not commonly consumed by the healthy individuals of the group [146], the consumption of plant parts with low nutritional value but rich in anti-nutritional compounds such as barks and roots [146] and the use of biologically active plants (Vernonia amygdalina and Trichilia rubescens). The later can be seen with some monarch butterfly females, which lay their eggs in toxic plants to preserve the infestation of larvae [147] or with some birds, which would plants to build their nests to prevent parasite affections [148, 149].

During our study period, plant parts (barks, marrow, and roots) were occasionally consumed by the mandrills. These plant parts, known as synthesis sites and reservoirs of non-nutritional compounds such as alkaloids, saponins, and tannin protect the plants against herbivorous [150153]. So, barks of Albizia gummifera, marrow of Costus afer and roots of Cnestis sp were occasionally consumed by mandrills. 
Phytochemical and pharmacological analyses of the barks of Albizia gummifera and marrows of Costus afer highlighted the richness in non-nutritional metabolites like alkaloids such as spermine, the most abundant one in Albizia gummifera, tannins, and saponins [48, 69], were revealed antimicrobial and antiprotozoal properties [150], suggesting that mandrills would use the plants for therapeutic or prophylactic purposes as reported by several works [13, 154-156]. This hypothesis was reinforced by the behavior of some wounded mandrills observed during our investigations.

Some male mandrills, suffering injuries as a result of fights among themselves, were observed, several times, rubbing themselves against the stem barks of Alchornea floribunda (Euphorbiaceae) only (Nsi Akoué, personal observations). These kind of fur-rubbing behaviors assimilated to the self-medication described on other species of primates such as capucins (Cebus capicinus) and orangs-outans [18, 157]. This could suggest that the stems of Alchornea floribunda could be used for curative purposes by the mandrills. Indeed, pharmacological studies on Alchornea floribunda revealed antibacterial activities against the Gram-negative (Bacillus cereus, Enterococcus faecalis, Staphylococcus aureus and Staphylococcus saprophyticus), Gram-positive (Escherichia coli, Klebsiella pneumoniae, Moraxella catarrhalis and Proteus mirabilis) [158], antiprotozoal activity on Trypanosoma brucei brucei, Trypanosoma cruzi, on Leishmania infantum and on the Plasmodium falciparum strain resistant to the chloroquine and to the pyrimenthamine [51].

The consumption of some plants with antiparasitic activity by the mandrills Lékédi Park could translate or explain a behavior of self-medication for the management of parasitic diseases as had already highlighted the Poirotte studies et al. [159]

Our ethnopharmacological surveys have revealed that 86 out of the 147 plant species eaten by mandrills were well-known by native populations. Several of these plants have a high use value (Table 3), especially food plants and some medicinal plants such as Thonningia sanguinea and Scleria boivinii, used in the whole Department to treat wounds and cough respectively.

The Fic values indicate the degree of shared knowledge for the treatment of the ailment by medicinal herbs [39]. Our results show the higher informant concensus factor (Fic) values of the majority categories indicating that the medicinal plants are effective in treating a certain diseases.

Among the mandrill food plants used by the native people, $41 \%$ were used as foods (e.g. Uapaca guineensis, Aframomum cf polyanthum and Aframomum daniellii), 33\% for medicinal purposes and mainly for the treatment of various affections such as gastrointestinal infections (e.g. Setaria megaphylla, Smilax anceps, Piptadeniastrum africanum, Cnestis ferruginea and Alchornea floribunda), and $11 \%$ were used both as food and as medicines (e.g. Microdesmis haumaniana, Smilax anceps). In that way, the use of several plants species included in non human primate diet by human primates as food or medicinal purposes are well documented (Cousins and Huffman, 2002; Krief et al., 2005; Petroni et al., 2016).

In that way, it was shown that some plant parts consumed by the mandrills are used in traditional medicine in the treatment of certain affections. The leaves of Alchornea floribunda and Craterispermum cerinanthum which are used for treat the malaria or fever, the marrow of Costus afer and leaves of Scleria boivinii and of Dichaetanthera africana are used in the treatement of cough and the stems of Scleria boivinii are used in the treatment genital tract diseases. 
Such similarities in plants used by both human and non-human primates for medicinal purposes have been reported [43, 144, 146], arguing that the Mandrillus sphinx' diet could be one of the pathways to the discovery of drugs to treat infectious diseases as suggested by other various works on animal self-medications [24, 144, 146]. This fact was attested by the worldwide ethnomedicinal uses of some plants species and their pharmacological properties reported in various ethnopharmacological studies. Alchornea floribunda, for example, is commonly used for the treatment of trypanosomiasis and microbial infections [36, 51, 160], chronic diarrhea, respiratory tract infections, abscess ovarian problems, ringworm and eczema [51, 161, 162]. Alchornea floribunda is reported also to exhibit anti-inflammatory and analgesic properties when applied topically and is commonly used for the treatment of arthritis, muscle pain, and other inflammatory disorders [183].

Pharmacological studies revealed activities against $\mathrm{gram}^{+}$and $\mathrm{Gram}^{-}$bacteria responsible for gastro-intestinal, skin, respiratory and urinary infections of Alchornea floribunda [164].

The decoction of the leaves Cnestis ferruginea is used by the Yoruba of South West Nigeria as a laxative, enema for dysentery and gonorrhea. The fruits are used locally for the treatment of tooth-ache, mouth and skin infections, it is also used for nasopharyngeal affections, pulmonary troubles and as analgesic, anti-inflammatory, antibacterial, and antifungal properties [64, 120, 121]. Setaria megaphylla would exert antiplasmodial activities [117]. Piptadeniastrum africanum would have antitumor, antimicrobial and anti-parasitic properties [51, 81] and Klainedoxa gabonensis, Landolphia hirsute, and Manniophyton fulvum commonly eaten by studied mandrill and also by chimpanzee populations from Salonga National Park, DR Congo for self-medication [21, 23] would have antibacterial, anti-parasitic properties and antidiarrheal activity on gastrointestinal motility [21, 165].

Fruits of Megaphrynium macrostachyum also consumed by the mandrills would exhibit antimicrobial activities against Escherichia coli, Shigella dysenteriae, Staphylococcus aureus, Enterococcus faecalis, Pseudomonas aeruginosa, and Candida albicans [166].

Palisota hirsuta would have antimicrobial and antiviral properties [99] and Myrianthus arboreus is reported to have antibacterial activities [93, 94].

Several species from the genus Aframomum, which are major food plants for the great apes throughout the lowland rainforest and many mountain areas [167-169], would exhibit a wide range of antibacterial and antifungal activities [153, 170]. It is the case of Aframomum daniellii for example, which is reported to have antimicrobial activities against Salmonella enteriditis, Pseudomonas fragi, P. fluoresecens, Proteus vulgaris, Streptococcus pyogens, Staphylococcus aureus, Aspergillus flavus A. parasiticus, A. ochraceus, and A. niger [171].

The resin of Aucoumea klaineana consumed occasionally by the mandrill is reported to have antifungal and antibacterial properties and is used by native people to purify water [58].

Concerning the plant parts used, some plant organs were used by the mandrills as well as by native people.

Indeed, the morrows of Costus afer, leaves of Setaria megaphylla and stems of Scleria boivinii were used by mandrills and humans.

However, for the large number of plants there were not similiraties in the parts of plants used by both human and non-human primates since humans, for medicinal puporses, rely mostly on leaves and barks [172-177]. Similar observations were eported by Petroni (2016) for who an 
explanation in the dissimilarities would be the fact of plants preparation forms in folk medicine in which leaves and barks are predominant and fruits being rarely used.

Among the forms of preparation, decoction was the method most used in preparing remedies. Our results are similar to those of other studies which have shown that decoction was the method most used in the consumption of drugs and that water was the good solvent for the preparation of the drugs in traditional medicine [178, 179].

\section{CONCLUSION}

Overall, our study which involved both zoopharmacological and ethnopharmacological approaches allowed us to highlight the floristic richness in nutritional and/or medicinal plants of La Lékédi Park (Bakoumba, South-Est Gabon). Some of the medicinal plants recorded may be useful for the management of various affections including infectious diseases and or neglected ones. Thus, the mandrill diet behaviour study may be a potential approach for the discovery drugs.

\section{ACKNOWLEDGMENT}

We thank the laboratory "CNRS-DPZ Mandrillus Project" and the staff of "Project Mandrillus" of Bakoumba, the Society of Exploitation of Lékédi Park (SODEPAL) and University of Sciences and Technique of Masuku (USTM) from Gabon for the financial and material support. We are also thankful to the Professor Do Ango from University Omar Bongo of Libreville and Mrs Sigride Asseko for their helpful comments, suggestions and also for their critical editing of the paper.

\section{REFERENCES}

1. Lafferty KD, Gerber LR. Good medicine for conservation biology: the intersection of epidemiology and conservation theory. Conserv. Biol. 2002; 16:593-604.

2. WHO. http://apps.who.int/iris/bitstream/10665/112642/1/9789241564748_eng.pdf. World Health Organisation, Geneve; 2014. p. 1-62.

3. World Malaria Report. World Health Organisation, Geneve; 2010. p. 51-62.

4. Pieter T, Johnson J, Paull SH. The ecology and emergence of diseases in fresh waters. Freshwater Biol. 2011; 56:638-657.

5. Carme B. Filariose lymphatique en République du Congo et éléphantiasis du scrotum. Bull Soc. Path. Ex. 2005; 98:363-364.

6. Huffman MA. Self-Medicative Behavior in the African Great Apes: An Evolutionary Perspective into the Origins of Human Traditional Medicine. Biosci. 2001; 51:652-661.

7. Reynolds V, Reynolds F. Chimpanzees of the Budongo forest. In: De Vore, I., (Ed). Primate Behaviour. Holt, Rinehart and Winston, New York; 1965. p. 368-424.

8. Schaller GB. The Mountain Gorilla: Ecology and Behaviour. Chicago and London. University of Chicago Press; 1963. p. 21.

9. Tutin, CEG, Fernandez M. Composition of the diet of chimpanzees and comparison with that of sympatric lowland gorillas in the Lopé reserve Gabon. A. J. Primatol. 1993; 30:195-211. 
10. Wrangham RW. Feeding behaviour of chimpanzees in Gombe National Park Tanzania. In: Clutton-Brock TH. (Ed). Primate Ecology: Studies of Feeding and Ranging Behaviour in Lemurs, Monkeys and Apes. New York, New York Academic Press; 1977. p. 503-538.

11. Dupain J, Van Elsacker L, Nell C, Garcia P, Ponce F, Huffman MA. New evidence for leaf swallowing and Oesophagostomum infection in Bonobos (Pan paniscus). Int. J. Primatol. 2002; 23:1053-1062.

12. Huffman MA, Elias R, Balansard G, Ohigashi H, Nansen P. L'automédication chez les singes anthropoïdes: une étude multidisciplinaire sur le comportement, le régime alimentaire et la santé. Primatol. 1998; 1:179-204.

13. Krief S, Huffman MA, Sévenet T, Hladik CM, Grellier P, Loiseau PM, Wrangham RW. Bioactive properties of plant species ingested by chimpanzees (Pan troglodytes schweinfurthii) in the Kibale National Park, Uganda. Am. J. Primatol. 2006; 68:51-71.

14. Wrangham RW, Nishida T. Aspilia spp leaves: a puzzle in the feeding behavior of wild chimpanzees. Primates. 1983; 24:276-282.

15. Dykstral CR, Hays JL, Simon MM. Selection of fresh vegetation for nest lining by redshouldered hawks. Wilds. J. Ornithol. 2009; 121:207-210.

16. Lambrechts MM, Dos Santos A. 2000. Aromatic herbs in Corsican blue tit nests: the 'Potpourri' hypothesis. Acta Oecologia. 21:175-178.

17. Ontiveros D, Caro J, Pleguezuelos JM. Green plant material versus ectoparasites in nests of Bonelli's eagle. J. Zoo. 2007; 6:1-6.

18. Baker M. Fur rubbing: use of medicinal plants by capucins monkeys (Cebus capucinus). Am. J. Primatol. 1996; 38:263-270.

19. DeJoseph M, Taylor RSL, Baker M, Aregullin M. Fur-rubbing behavior of capuchin monkeys. J. Am. Acad. Dermatol. 2002; 46:924-925.

20. Valderrama X, Robinson JG, Attygalle AB, Eisner T. Seasonal anointment with millipedes in a wild primate: a chemical defense against insects? J.Chem. Ecol. 2000; 26:2781-2790.

21. Ahoua ARC, Konan AG, Bonfoh B, Koné MW. Antimicrobial potential of 27 plants consumed by chimpanzees (Pan tronglodytes verus Blumenbach) in Ivory Coast. BMC Com. Alt. Med. 2015; 15:383.

22. Fowler A, Koutsioni Y, Sommer V. Leaf-swallowing in Nigerian chimpanzees: evidence for assumed selfmedication, Primates. J. Primatol. 2007; 48:73-76.

23. Fruth B, Ikombe NB, Matshimba GK, Metzger S, Muganza DM, Mundry R, Fowler A. New Evidence for Self-Medication in Bonobos: Manniophyton fulvum Leaf-and StemstripSwallowing from Lui-Kotale, Salonga National Park, DR Congo. Am. J. Primatol. 2014; 76, 146-158.

24. Ngbolua KTN, Bolaa Bokamba M, Mpiana PT, Ekutsu EG, Ashande MC, Tshibangu DST, Mudogo V, Tshilanda DD, Kowozogono RK. Great apes plant foods as valuable alternative of traditional medicine in Congo Basin: The case of non-human primate Bonobos (Pan paniscus) diet at Lomako Fauna Reserve, Democratic Republic of the Congo. J. Adv. Bot. Zoo. 2015; 3:1-5.

26. Peignot $\mathrm{P}$, Charpentier MJE, Bout N, Bourry O, Massima U. Learning from the first release project of captive-bred mandrills (Mandrillus sphinx) in Gabon. Oryx. 2008; 42:122-131. 
27. Brockmeyer T, Kappeler PM, Willaume E, Benoit L, Mboumba S, Charpentier MJE. Social Organization and Space Use of a Wild Mandrill (Mandrillus sphinx) Group. Am. J. Primatol. 2015; 9999:2-13.

28. Altmann J. Observational study of behaviour: Sampling methods. Behaviour. 1974; 49:227267.

29. Koechlin J. Musaceae, Sterelitziaceae, Zingiberaceae, Cannaceae and Marantaceae. Flore du Gabon Scitaminales. 1964; 9:33-157.

30. Le Thomas A. Flore du Gabon-les Annonaceae, 1969; 16:9-231.

31. Letouzey R. Manuel Botanique Forestière Afrique Tropicale. Tome 2 A; $2^{\mathrm{e}}$ Edition; 1983. p. 64-199

32. White L. Abernethy K. Guide de la Végétation de la Réserve de la Lopé Gabon. $1^{\text {re }}$ Edition; 1996. p. $56-125$

33. Walker R, Sillans S. Plantes Utiles du Gabon. Edition Lechevalier, Sepi; 1961. p 210-384.

34. Wilks CM, Issembé YA. Guide pratique d'identification: les arbres de la Guinée Equatoriale, Région Continentale Projet Curef; 2000. p 274-294.

35. Mboyi Moukanda LC. La pratique des échanges commerciaux dans la société précoloniale du Gabon:XVI ${ }^{\mathrm{e}}-\mathrm{XIX}^{\mathrm{e}}$ siècles.Thesis of University of Michel of Montaigne-Bordaux III; 2013. p. 66-70.

36. Adjanohoun E, Aboubakar N, Dramane K, Ebot ME, Ekpere JA, Enow-Orock EG, Focho D, Gbilé ZO, Kamanyi A, KamsuKom J, Keita A, Mbenkum T, Mbi CN, Mbiele AL, Mbome IL, Mubiru NK, Nancy WL, Nkongmeneck B, Satabié B, Sofowora A, Tamze V, Wirmum CK. Traditional Medicine and Pharmacopoeia: Contribution to Ethnobotanical and Floristic Studies in Cameroon, CSTR/OUA; 1996. p 22-35.

37. Höft M, Barik SK, Lykke AM. Quantitative ethnobotany. Applications of multivariate and statistical analyses in ethnobotany. People and plant working paper; 1999.

38. Trotter RJ, Logan MH. Informant consensus. A new approach for identifying potentially effective medicinal plants. In: Etkin NL, editor. Plants in indigenous medicine and diet. Bedford Hills: Newyork: Redgrave; 1986. p 91-112.

39. Heinrich M, Ankli A, Frei B, Weimann C, Sticher O. Medicinal plants in Mexico: healers' consensus and cultural importance. Social Sci Med. 1998; 47:1859-1871.

40. Kuete V, Ango PY, Yeboah SO, Mbaveng AT, Mapitse R, Kapche GDWF, Ngadjui BT, Efferth T. Cytotoxicity of four Aframomum species (A. arundinaceum, A. alboviolaceum, A. kayserianum and $A$. polyanthum) towards multi-factorial drug resistant cancer cell lines. BMC Com. Alt. Med. 2014; 14:340-347.

41. Koné M, Kamanzi AK. Inventaire ethnomédical et évaluation de l'activité anthelminthique des plantes médicinales utilisées en côte d'ivoire contre les helminthiases intestinales. Pharmac. Méd. Trad. Afr. 2006; 14:52-72.

42. Dorianne ED, Jaures AK, Jackson AS, Aime GF, Igor KV, Simplice BT, Antoine HL, Nkuete. Antibacterial activity of selected edible plant extracts against multidrug-resistant Gram-negative bacteria. BMC Com. Alt. Med. 2013; 13:164.

43. Cousins D, Muffman M. Medicinal properties in the diet of gorillas: an ethnopharmacological evaluation; Afr. St. Monogr. 2002; 23:65-89. 
44. Betti JL. An ethnobotanical study of medicinal plants among the Baka Pygmies in the Dja Biosphere Reserve, Cameroon. Afr. St. Monogr. 2004; 25:1-27.

45. Diehl MS, Kamanzi K, Téré H, Betschart B. Prospect for anthelmintic plants in the Ivory Coast using ethnobotanical criteria. J. Ethnopharmacol. 2004; 3:277-284.

46. Noumi E, Yomi A. Medicinal plants used for intestinal diseases in Mbalmayo Region. Central Province, Cameroon. 2001; 72:246-254.

47. Geyid A, Abebe D, Debella A, Makonnen Z, Aberra F, Teka F, Kebebe T, Urga K, Yersaw K, Biza T, Mariam BH, Guta M. Screening of some medicinal plants of Ethiopia for their anti-microbial properties and chemical profiles. J. Ethnopharmacol. 2005; 97:421-427.

48. Rukunga GM, Muregi FW, Tolo FM, Omar SA, Mwitari P, Muthaura CN, Kraus W, KofiTsekpo WM. The antiplasmodial activity of spermine alkaloids isolated from Albizia gummifera. Fitoterapia. 2007; 78:455-459.

49. Tekwu EM, Pieme AC, Beng PV. Investigation of antimicrobial activity of some Cameroonian medicinal plant extracts against bacteria and yeast with gastrointestinal relevance. J. Ethnopharmacol. 2012; 142:265-273.

50. Okoye FBC, Osadebe PO. Studies on the mechanisms of anti-inflammatory activity of the extracts and fractions of Alchornea floribunda leaves. Asian Pacific J. Trop. Med. 2009. 2:714.

51. Musuyu Muganza D, Fruth BI, Nzunzu Lami J, Mesia GK, Kambu OK, Tona GL, Cimanga Kanyanga R, Cos P, Maes L, Apers S, Pieters L. In vitro antiprotozoal and cytotoxic activity of 33 ethonopharmacologically selected medicinal plants from Democratic Republic of Congo. J. Ethnopharmacol. 2012; 141:301-308.

52. Ndebia EJ, Nkeh-Chungag BN, Temdie JR, Fodjo YM, Ndinteh DT, Mbafor JT. Antinoceptive effects of the methanol extract of Uapaca guineensis (Euphorbiaceae) still root bark. Pharmacologyonline. 2007; 3:153-165.

53. Nkeh-Chungag BN, Temdie JR, Sewani-Rusike C, Fodjo YM, Mbafor JT, Iputo JE. Analgesic, anti-inflammatory and antiulcer properties of the extract of Uapaca guineensis (Euphorbiaceae). J. Med. Plants Res. 2009; 3:635-640.

54. Kémeuzé VA, Nkongmeneck BA. Antrocaryon klaineanum Pirre. In: Lemmens RHM, Louppe D, Oteng-Amoako AA. (Eds.), Prota 7(2): Timbers/ Bois d'œuvre 2. [CD-Rom]. Prota, Wageningen: Nertherlands; 2011. p. 85-88.

55. Abogo Mebale AJ, Massimba Dibama H, Ntsame Affane AL, Moumbangou Nzigou S, Ndoume Ollame J, Ondo JA, Eba F. Phytochemical analyses of aqueous extracts of two medicinal plants from Gabon: Pseudospondias longifolia and Antrocaryon klaineanum. J. Nat. Sci. Res. 2013; 3:175-177.

56. Douanla PD, Tabopda TK, Tchinda AT, Cieckiewicz E, Frédérich M, Boyom FF, Tsabong $\mathrm{N}$, Yeboah S, Nkengfack AE, Tchuendem MHK. Antrocarines A-F, antiplasmodial ergostane steroids from the stem of Antrocaryon klaineanum. Phytochem. 2015; 117:521526.

57. Ondo JP, Obame LC, Andzi-Barhé T, Nsi Akoué G, Nsi-Emvo E, Lebibi J. Phytochemical screening, total phenolic content and antiradical activity of Asplenium africanum (Aspleniaceae) and fruit of Megaphrynium macrostachyum (Marantaceae). J. Appl. Pharmac. Sci. 2013; 3:92-96. 
58. Obame Engonga LC, Bongui JB, Andzi Barhé T, Ondo JP, Edou Engonga P, Koudou J. Antifungal and antibacterial of Aucoumea klaineana Pierre Essential oil from Gabon. Vedic Res. Int. Phytomed. 2014; 2:17-21.

59. Dhawan K, Dhawan S, Sharma A. Passifloraceae: a review update. J. Ethnopharmacol. 2004; 94:1-23.

60. Ingale AG, Hivrale AU. Pharmacological studies of Passifloraceae and their bioactive compounds. Afr. J. Plant Sci. 2010; 4:417-426.

61. Nene Bi SA, Traore F, Soro TY, Souza A. Etudes phytochimique et pharmacologique de Bridelia ferruginea benth (Euphorbiaceae) sur la motricité du tania coli de cobaye. Afr. Sci. 2009; 5, 305-320.

62. Adetutu A, Winston A, Morgan, Corcoran O. Antibacterial, antioxidant and fibroblast growth stimulation activity of crude extracts of Bridelia ferruginea leaf, a wound-healing plant of Nigeria. J. Ethnopharmacol. 2011; 133:116-119.

63. Ugbogu OC, Akukwe AR. The antimicrobial effect of oils from Pentaclethra macrophylla Bent, Chrysophyllum albidum G. Don and Persea gratissima Gaerth F on some local clinical bacteria isolates. Afr. J.Biotechnol. 2009; 8:285-287.

64. Ishola IO, Ashorobi RB. Anti-stress potential of extract aqueous root of Cnestis ferruginea. Int. J. Pharmacol. 2007; 3:295-298.

65. Ismail O, Ishola, Abidemi J, Akindele, Olufunmilayo, Adeyemi O. Analgesic and antiinflammatory activities of Cnestis ferruginea Vahl ex DC (Connaraceae) methanolic root extract. J. Ethnopharmacol. 2011; 2:24.

66. Akharaiyi FC, Bolatito Boboye B, Adetuyi FC. Antibacterial, phytochemical and antioxidant properties of Cnestis ferruginea DC (Connaraceae) extracts. J. Mic. Biot. Food Sci. 2012; 2:592-609.

67. Etukudo I. Ethnobotany, Conventional and Traditional uses of Plants Vol. 1[1st edition] Uyo, Nigeria, Verdict Press; 2003. p. 257-262.

68. Akpan MM, Odeomena CS, Nwachukwu CN, Danladi B. Antimicrobial assessment of ethanolic extract of Costus aferLeaves. Asian J. Plant Sci. Res. 2012; 2:335-341.

69. Akaninwor JO, Essien EB, Ayakeme T, Uvoh SM. Phytoconstituents of Costus afer methanolic stem extract and its in vitro radical scavenging activities. J. Agri. Biod. Res. 2014; 3:99-110.

70. Ondo JP. Etude phytochimique et evaluation de l'activité antiplasmodiale de Vitex madiensis Oliv. (Lamiaceae) et de Croton mayumbensis (Euphorbiaceae), plantes médicinales gabonaises. Thesis of University of Rouen; 2011. pp 86-90.

71. Mpiana PT, Tshibangua DST, Shetondea OM, Ngboluab KN. In vitro antidrepanocytary activity (anti-sickle cell anemia) of some Congolese plants. Phytomed. 2007; 14:192-195.

72. Onkwu DE, Nnamdi FU. Evaluation of the chemical composition of Dacryodes edulis and Raphia hookeri Mann and wend exudates used in herbal medicine in South-Eastern Nigeria. Afr. J. Trad. Com. Alt. Med. 2008; 5:194-200.

73. Majesty D, Chioma A, Amadike U, Adindu E, Benjamin A. Phytochemical, vitamin and proximate composition of Dacryodes edulis fruit at different stages of maturation. Asian J. Plant Sci. Res. 2012; 2:437-441. 
74. Nsi Akoué G, Obame LC, Ondo JP, Ibrahim B, Otogo ES, N'Nang SYT, Souza A. Phytochemical composition and antiradical activity of Sakersia africana Hook.f. Medicinal plant from Gabon. Int. J. Biomol. Biomed. 2013; 3:1-8.

75. Burkill HM. The useful plants of West Tropical Africa. 2nd Ed. vol. 3, Families J-L.Royal Botanic Gardens, Kew, Richmond, United Kingdom; 1995. p. 857.

76. Ngulefack EMP, Ngu KP, Atchade A, Dimo T, Tsabang N, Mbafor JT. Phytochemical composition and in vitro effects of the ethyl acetate bark extract of Distemonanthus benthamianus Bailon (Caesalpiniaceae) on Staphylococcus aureus and Streptococcus agalactiae. Cameroon. J. Exp. Biol. 2005; 1:50-53.

77. Bidie AdP, Banga B, N'Guessan, Adou F, Yapo, N'Guessan JD, Djaman AJ. Activités antioxydantes de dix plantes médicinales de la pharmacopée ivoirienne. Sci. Nat. 2011; 8:111.

78. Chong KH, Zuraini Z, Sasidharan S, Kalnisha Devi PV, Yoga L, Latha, Ramanathan S. Antimicrobial activity of Elaeis guineensis Leaf. Pharmacologyonline. 2008; 3:379-386.

79. Kemka-Evans CI, Ngumah MO, Nwachukwu CU, Ugochukwu N. Comparative evaluation of phytochemical and antimicrobial activities of Elaeis guineensis tusks, Musa paradisiaca peels and potassium carbonate on bacteria isolate from fermented Pentaclethra macrophylla seeds. J. Glob. Biosci. 2013; 2:17-19.

80. Ahoua ARC, Kone MW, Konan AG, Tra Bi FH, Bonfoh B, Antioxidant activity of eight plants consumed by great apes in Côte d'Ivoire. Afr. J. Biot. 2012; 11:11732-11740.

81. Onanga M, Ekouya E, Ouabonzi A, Itoa GB. Etudes ethnobatanique, pharmacologique et chimique des plantes utilisées dans le traitement des dermatoses "Mwandza". Pharmac. Méd. Trad. Afr. 1997; 9:85-93.

82. Awah FM, Uzoegwu PN, Ifeonu P, Oyugi JO, Rutherford J, Yao X, Fehrmann F, Fowke KR, Eze MO. Free radical scavenging activity, phenol contents and cytotoxicity of selected Nigerian medicinal plants. Food Chem. 2012; 131:1279-1286.

83. Tona L, Kambu K, Ngimbi N, Cimanga K, Vlietinck AJ. Antiamoebic and phytochemical screening of some Congolese medicinal plants. J. Ethnopharmacol. 1998; 61:57-65

84. Muanza DN, Kim KL, Euler L. Antibacterial and antifungal activities of nine medicinal plants from Zaïre. Int. J. Pharmacol. 1994; 32:337-345.

85. Valdés AFC, Martínez JM, Lizama RS, Gaitén YG, Rodríguez DA, Payrol JA. In vitro Antimalarial activity and cytotoxicity of some selected Cuban medicinal plants. Rev. Int. Med. Trop. Sao Paulo. 2010; 52:197-201.

86. Sahrawat A, Pal S, Shahi SK. Antibacterial activity of Manguifera indica (mango) leaves against drug resistant bacterial strains. Int. J. Adv. Res. 2013; 6:82-86.

87. Emudainohwo, Tedwins JO. Antibacterial properties of ethanol and aqueous root extract of Manniophyton fulvum. Arch. Biomed. Sci. Health. 2014; 2:27-34.

88. Bagre I, Bahi C, Gnahoue G, Djaman AJ, Guede GF. Composition phytochimique et évaluation in vitro de l'activité antifongique des extraits des feuilles de Morinda morindoides (baker) milne-redhead (Rubiaceae) sur Aspergillus fumigatus et Candida albicans. J. Sci. Pharmacol. Biol. 2007; 1, 15-23.

89. Imam MZ, Akter S. Musa paradisiaca L. and Musa sapientum L. A phytochemical and pharmacological review. J. Appl. Pharmac. Sci. 2011; 1:14-20. 
90. Karadi RV, Arpan Shah, Parekh P, Azmi P. Antimicrobial activities of Musa paradisiaca and Cocos nucifera. Int. J. Res. Pharmac. Biomed. Sci. 2011; 2:264-267.

91. Razafindraibe M, Kuhlman AR, Rabarison H, Rakotoarimanana V, Rajeriarison C, Rakotoarivelo N, Randrianarivony T, Rakotoarivony F, Ludovic R, Randrianasolo A, Bussmann RW. Medicinal plants used by women from Agnalazaha littoral forest (Southeastern Madagascar). J. Ethnobiol. Ethnomed. 2013; 9:73.

92. Adeneye AA, Ajagbonna OP, Ayodele OW. Hypoglycemic and antidiabetic activities on the stem bark aqueous and ethanol extracts of Musanga cecropioides in normal and alloxaninduced diabetic rats. Fitoterapia. 2007; 78:502-505.

93. Agwa OK, Chuku W, Obichi EA. The in vitro effect of Myrianthus arboreus leaf extract on some pathogenic bacteria of clinical origin. J. Mic. Biot. Res. 2011; 1:77-85.

94. Borokini TI, Omotayo FO. Comparative Phytochemical Analysis of selected medicinal plants in Nigeria. Int. J. Adv.Chem. Res. 2012; 1:11-18.

95. Deeni YY, Hussain HSN. Screening for antimicrobial activity and for alkaloids of Nauclea latifolia. J. Ethnopharmacol. 1991; 35:91-96.

96. Lamidi ME, Ollivier R, Faure R, Debrauwer L, Nze-Ekekang L, Balansard G. Quinovic acid glycosid from Nauclea diderichii. Planta Med. 1995; 61:280-281.

97. Benoit-Vecal, F., Valentin, A., Cournac, V., Prélissier, Y., Mallié, M., Bastide J.M., 1998. In vitro antiplasmodial activity of stem and root extracts of Nauclea latifolia Smith (Rubiaceae). J. Ethnopharmacol. 61, 173-178.

98. Onyeyili PA, Nwosu CO, Amin JD, Jibike JI. Anthelmintic activity of crude aqueous extract of Nauclea latifolia stems bark against ovine nematodes. Fitoterapia. 2001; 72:12-21.

99. Anani K, Hudson JB, de Souza C, Akpagana K, Tower GHN, Arnason JT, Gbeassor M. Investigation of medicinal plants of Togo for antiviral and antimicrobial activities. Pharma. Biol. 2000; 38:40-45.

100. Ndiaye M, Diatta W, Sy AN, Dièye AM, Faye B, Bassène E. Antidiabetic properties of aqueous bark extract of Parinari excelsa in alloxan-indced diabetic rats. Fitoterapia. 2008; 79:267-270.

101. Ajaiyeoba, Edith O. Phytochemical and antibacterial properties of Parkia biglobosa and Parkia bicolor leaf extracts. Afr. J. Biomed. Res. 2002; 5:125-129.

102. Bonnah B, Aklikokou KA, Akpagana K, Gbeassor M. Contribution à l'étude des propriétés pharmacologiques des extraits hydro-alcooliques de graines de Parkia biglobosa. Sciences et Médecine. Rev. CAMES. 1998; 00:12-15.

103. Assane M, Baba Moussa R, Bassene E, Sere A. Etude de l'action anti-hypertensive des graines de Parkia biglobosa.(Jacq). Benth chez le rat. Dakar-medica. 1993; 28:49-54.

104. Kouadio F, Kanko C, Juge M, Grimaud N, Jean A, N'guessan YT, Petit JY. Analgesic and anti-inflammatory activities of an extract from Parkia biglobosa used in traditional medicine in the Ivory Coast. Phyt. Res. 2000; 14:635-637.

105. Akaneme FI, Igata D, Okofor H, Anyenbechi O. Breeding for nutritional quality for Corchorus olitorius, Annona muricata and Pentaclethra macrophylla: A study of their antinutritional contents. Afr. J. Agri. Res. 2014; 9:1107-1112. 
106. Adeyemi OO, Okpo SO, Ogunti OO. Analgesic and anti-inflammatory effects of the aqueous extract of leaves of Persea americana Mill. (Lauraceae). Fitoterapia. 2002; 73:375380.

107. Nayak BS, Raju SS, Chalapathi-Rao AV. Wound healing activity of Persea americana (avocado) fruit: a preclinical study on rats. J. Wound Care. 2008; 17:123-126.

108. Raharjo SHT, Gomez-Lim WMA, Padilla G, Litz RE. Recovery of avocado (Persea americanaMill.) plants transformed with the antifungal plant defensing gene PDF12. In vitro Cellular Developmental Biology, 2008; 44:254-262.

109. Anaka ON, Ozolua RI, Okpo SO. Effect of the aqueous seed extract of Persea americana Mill. (Lauraceae) on the blood pressure of Sprague dawley rats. Afr. J. Pharma. Pharmacol. 2009; 3:485-490.

110. Kosińska A, Karamác M, Estrella I, Hernández T, Bartolomé B, Dykes GA. Phenolic compound profiles and antioxidant capacity of Persea americana Mill. peels and seeds of two varieties. J. Agri. Food Chem. 2012; 60:4613-4619.

111. Vinha AF, Moreira J, Barreira SVP. Physicochemical parameters, phytochemical composition and antioxidant activity of the algarvian avocado (Persea americanaMill.). J. Agri. Sci. 2013; 5:100-109.

112. Yemoa AL, Gbenou JD, Johnson RC, Djego JG, Zinsou C, Moudachir M, Quetin-Leclercq J, Bigot A, Portaels F. Identification et étude phytochimique de plantes utilisées dans le traitement traditionnel de l'ulcère de Buruli au Bénin. Pharmacol. 2008; 42:48-55.

113. Noumi E, Tchakonang NYC. Plants used as abortifacients in the Sangmélima region of southern Cameroon. J. Ethnopharmacol. 2000; 76:263-267.

114. Gangoué-Piéboji J, Pegnyernb DE, Niyitegeka D, Nsangou A, Eze N, Minvem C, Ngo Mbing, Ngassam P, Ghogomu Tih R, Sodengam BL, Bodo B. In vitro antimicrobial activity of sorne medicinal plants from Cameroon. Pharmaco. Med. Tra. Afr. 2004; 13:161-173.

115. Kimbi SF, Keumedjio F, Sondengam LB, Connolly JD. Two dinorditerpenoids from Ricinodendron heudelotii. Phytochem. 1991; 30:619-621.

116. Agyare C, Asase A, Lechtenberg $M$, Niehues $M$, Deters A, Hensel A. An ethnopharmacological survey and in vitro confirmation of ethnopharmacological use of medicinal plants used for wound healing in Bosomtwi-atwima-kwanwoma area, Ghana. J. Ethnopharmacol. 2009; 125:393-403.

117. Okokon JE, Bassey AL, Nwidu LL. Antidiabetic and Hypolipidaemic Effects of ethanolic root extract of Setaria megaphylla. Int. J. Pharmacol. 2007; 3:91-95.

118. Paul A, Nwafor, Ekpo M, Udezi WT, Okokon J, Bassey AL. Acute toxicity potential of methanolic extract of Anceps kraussiana leaves in Rats. Int. J. Pharmacol. 2006; 2:463-466.

119. Hamid AA, Aiyelaagbe OO. The screening of phytoconstituents, antibacterial and antifungal properties of Smilax kraussiana leaves. Pelagia Research Library Der Pharmacia Sinica 2011; 2:267-273.

120. Sandhul PS, Baljinder Singh, Vikas Gupta, Bansal P, Kumar D. Potential Herbs Used in Ocular Diseases. J. Pharmac. Sci. Res. 2011; 3:1127-1140.

121. Anwana ED, Umana EJ, Lennox JA. Antimicrobial Potential of Ten Common Medicinal Plants used by the Bokis, Cross River State, Nigeria. Med. Ar. Plants. 2012. p. 106. 
122. N'guessan JD, Dinzedi MR, Guessennd N, Coulibaly A, Dosso MAJ, Djaman AJ, GuedeGuina F. Antibacterial activity of the aqueous extract of Thonningia sanguinea against Extended-Spectrum- $\beta$ - Lactamases (ESBL) producing Escherichia coli and Klebsiella pneumoniae strains. Trop. J. Pharmac. Res. 2007; 6:779-783.

123. Hoshino J. Feeding ecology of mandrills (Mandrillus sphinx) in Campo animal reserve, Cameroon. Prim. 1985; 26:248-273.

124. Lahm SA. Diet and habitat preference of Mandrillus sphinx in Gabon: Implications of Foraging Strategy. Am. J. Primatol. 1986; 11:9-26.

125. Norris J. Diet and Feeding Behavior of Semi-free Ranging Mandrills in an Enclosed Gabonese Forest. Prim. 1988; 29:449-463.

126. Glander KE. The impact of secondary compounds on primate feeding behaviour. Year book Phys. Anthropol. 1982; 25:1-18.

127. Magliocca F., Gautier-Hion A. Mineral content as a basis for food selection by western lowland gorillas in a forest clearing. Am. J Primatol. 2002; 57:67-77.

128. Simmen B, Hladik CM. Sweet and bitter taste discrimination in Primates: Scaling effects across species. Folia Primatol. 1998; 69:129-138.

129. Kaplin BA, Moermond TC. Foraging ecology of the mountain monkey (Cercopithecus l'hoesti): implications for its evolutionary history and use of disturbed forest. Am. J. of Primatol. 2000; 50, 227-246.

130. Malenky RK, Stiles EW. Distribution of terrestrial herbaceous vegetation and its consumption by Pan paniscus in the Lomako Forest, Zaire. Am. J. Primatol. 1991; 23:153169.

131. Nishihara T. Feeding ecology of western lowland gorillas in the Nouabale-Ndoki National Park, Congo. Prim. 1995; 36:151-168.

132. Rothman JM, Dierenfeld ES, Molina DO, Shaw AV, Hintz HF, Pell AN. Nutritional Chemistry of Foods Eaten by Gorillas in Bwindi Impenetrable National Park, Uganda. Am. J. Primatol. 2006; 68:675-691.

133. Alinnor IJ, Oze R. Chemical evaluation of the nutritive value of Pentaclethra macrophylla benth. (African oil bean) seeds. Pak. J. Nutri. 2011; 10:355-359.

134. Amata IA. Nutritional value of the leaves of Myrianthus arboreus: A Browse plant. Int. J. Agri. Res. 2010; 5:576-581.

135. Dike MC. Proximate, phytochemical and nutrient compositions of some fruits, seeds and leaves of some plant species at Umudike, Nigeria. J. Agri. Biol. Sci. 2010; 5, 7-16.

136. Milton K. Factors influencing leaf choice by howler monkeys: a test of some hypotheses of food selection by generalist herbivores. Am. Natur. 1979; 114:362-378.

137. Oftedal OT. The nutritional consequences of foraging in primates-the relationship of nutrient intakes to nutrient-requirements. Philosophical Transactions of the Royal Society of London Series B-Biological Sci. 1991; 334:161-170.

138. Rothman JM, Dierenfeld ES, Hintz HF, Pell AN. Nutritional quality of gorilla diets: consequences of age, sex, and season. Oecologia 2008; 155:111-122.

139. Felton AM, Felton A, Lindenmayer DB, Foley WJ. Nutritional ecology, nutritional goals of wild primates. Func. Ecol. 2009; 23:70-78. 
140. Milton K. Micronutrient intakes of wild primates: Are humans different? Comparative Biochemistry and Physiology-Part A: Molecular and Integrative Physiology. 2003; 136, 47 59.

141. Hladik CM. Composition biochimique des fruits et perception gustative : interactions et tendances évolutives dans les forêts tropicales. In Hladik, C.M., Hladik, A., Pagezy, H., Linares, O.F., Koppert, G.J.A., Froment, A., (Eds.), L'alimentation en forêt tropicale : interactions bio-culturelles et perspectives de développement, UNESCO Paris; 1996. p.145164.

142. Singh JP, Babcock DF, Lardy HA. Increased calcium-ion influx is a component of capacitation in spermatozoa. Biochem. J. 1978; 172:549-556.

143. Triana LR, Babcock DF, Lorton SP, First NL, Lardy HA. Release of acrosomal hyaluronidase follows increased membrane permeability to calcium in the presumptive capacitation sequence for spermatozoa of the bovine and other mammalian species. Biol. Reproduc. 1980. 23, 47-59.

144. Huffman MA. Animal self-medication and ethno-medicine: exploration and exploitation of the medicinal properties of plants. Proc. Nutri. Soc. 2003; 62:371-381.

145. Huffman MA, Seifu M. Observations on the illness and consumption of a possibly medicinal plant Vernonia amygdalina (Del.), by a wild chimpanzee in the Mahale Mountains National Park, Tanzania. Prim. 1989; 30:51-63.

146. Krief S, Hladik CM, Haxaire C. Ethnomedicinal and bioactive properties of plants ingested by wild chimpanzees in Uganda. J. Ethnopharmacol. 2005; 101:1-15.

147. Lefèvre T, Oliver L, Hunter MD, de Roode JC. Evidence for trans-generational medication in nature. Ecol. Letters 2010; 13:1485-1493.

148. Clark L, Mason JR. Use of nest material as insecticidal and anti-pathogenic agents by the European starling. Oecologia. 1985; 67:169-176.

149. Wimberger PH. The use of green plant material in bird nests to avoid ectoparasites, Auk 1984; 101:615-618.

150. Bruneton J. Pharmacognosie, phytochimie, plantes médicinales. Technique \& documentation. Lavoisier, Paris; 2009. p. 458-953

151. Hladik CM. Aliments et médicaments: des «traditions » chez les chimpanzés et de leurs interprétations; Editions errance, paris; 1998. p 151-161.

152. Mpondo PT, Ngbolua KN, Mudogo V, Tshibangu DST, Atibu EK, Mbala BM, Kahumba B, Bokota MT, Makelele LT. The potential effectiveness of medicinal plants used for the treatment of sickle cell disease in the Democratic Republic of Congo folk medicine: A review. In: Gupta,VK,Singh GD. (Eds), Traditional and Folk herbal Medicine, Daya Publishng House, New Delhi 2012; 1:1-11.

153. Wrangham RW, Conklin NL, Chapman CA, Hunt KD. The significance of fibrous foods for Kibale forest chimpanzees. Philosophical transactions of the Royal Society of London, Series B 1991; 334:171-178.

154. Huffman MA, Gotoh S, Turner L, Yoshida K. Seasonal trends in intestinal nematode infection and medicinal plant use among chimpanzees in the Mahale Mountains, Tanzania. Prim. 1997; 38:111-125. 
155. Huffman MA, Gotoh S, Izutsu D, Koshimizu K, Kalunde MS. Further observations on the use of Vernonia amygdalina by a wild chimpanzee, its possible effect on parasite load, and its phytochemistry. Afr. St. Monogr. 1993; 14:227-240.

156. Phillips-Conroy JE. Baboons, diet, and disease: Food plant selection and schistosomiasis. In: Taub D.M., King F.A., (Eds). Current perspectives in primate social dynamics, New York, Van Nostrand Reinhold; 1986. p 287-304.

157. Morrogh-Bernard HC. Fur-rubbing as a form of self-medication in Pongo pygmaeus. Int. J. Primatolo. 2008; 29:1059-1064.

158. Noundou XS, Krause RWM, Vuuren SFV, Tantoh Ndinteh D, Olivier DK. Antibacterial activity of the roots stems and leaves of Alchornea floribunda. J. Ethnopharmacol. 2014; 151:1023-1027.

159. Poirotte C, Basset D, Willaume E, Makaba F, Kappeler PM, Charpentier MJE. Environmental and individual determinants of parasite richness across seasons in a treeranging Population of Mandrills (Mandrillus sphinx). Am. J. Phy. Anthropol. 2015; 159:114.

160. Jiofack T, Ayissi I, Fokunang C, Guedje N, Kemeuze V. Ethnobotany and phytomedicine of the upper Nyong valley forest in Cameroon. A. J. Pharm. Pharmacol. 2009; 3:144-150.

161. Mesia GK, Tona GL, Nanga TH, Cimanga RK, Apers S, Cos P, Maes L, Pieters L, Vlietinck AJ. Antiprotozoal and cytotoxic screening of 45 plant extracts from Democratic Republic of Congo. J. Ethnopharmacol. 2008; 115:409-415.

162. Mosango DM. Alchornea floribunda Müll.Arg. [Internet] Record from Protau. In: Schmelzer, GH, Gurib-Fakim A. (Eds.), PROTA (Plant Resources of Tropical Africa/Ressourcesvégétales de l'Afriquetropicale). 2007. p 78.

163. Duke, J.A., Mary, J.B., Judi, D., Handbook of medicinal herbs. Boca Raton. CRC Press; 2002. p 24-36.

164. Eloff JN. A sensitive and quick microplate method to determine the minimal inhibitory concentration of plant extracts for bacteria. Planta Med. 1998; 64:711-713.

165. Ojieh EA, Adegor CE, Ovuakporaye IS, Ewhre OL. Preliminary phytochemical screening and antidiarrheal properties of Manniophyton fulvum. J. Dental Med. Sci. 2013; 10:46-52.

166. Sima Obiang, C, Ondo J-P, Obame Engonga L-C, Padzys G-S, Zongo C, Bongui J-B, Nsi Emvo E, Traore A. Phytochemical screening, evaluation of antioxidant and antimicrobial properties of Erythrophleum ivorense A. Chev (Leguminosae) and Megaphrynium macrostachyum Benth (Marantaceae), medicinal plants from Gabon. Int. J. Biosci. 2016; 8:43-53.

167. Nishida T, Uehara S. Natural diet of chimpanzees (Pan troglodytes schweinfurthii): Long term record from the Mahale Mountains, Tanzania. Afr. St. Monog. 1983; 3:109-130.

168. Tutin CEG, White LJT, Williamson EA, Fernandez M, McPherson G. List of plant species indentified in the northern part of the Lopé Reserve, Gabon. Tropics 1994; 3:249-276.

169. Wrangham RW, Rogers ME, Isabirye-Basuta G. Ape food density in the ground layer in Kibale forest, Uganda. Afr. J. Ecol. 1993; 31:49-57.

170. Kuroda S, Nishihara T, Suzuki S, Oko RA. Sympatric chimpanzees and gorillas in the Ndoki Forest, Congo. In: McGrew WC, Marchant LF, Nishida T. (Eds.). Great Ape Societies, Cambridge, Cambridge University Press; 1996. p. 71-81. 
171. Adegoke GO, Skura BJ. Nutritional profile and antimicrobial spectrum of the spice Aframomum daniellii. Plant Foods for Human Nutri. 1994; 45:175-182.

172. Asiimwe S, Kamatenesi-Mugisha M, Namutebi A, Borg-Karlsson A-K, Musiimenta P. Ethnobotanical study of nutri-medicinal plants used for the management of HIV/AIDS opportunistic ailments among the local communities of western Uganda. J. Ethnopharmacol. 2013; 150:639-648.

173. Kisangau DP, Lyaruu HVM, Hosca KM, Joseph CC. Use of traditional medicines in the management of HIV/AIDS opportunistic infections in Tanzania: a case in the Bucoba rural district. J. Ethno. Ethnomed. 2007; 3:29.

174. Lamorde M, Tabuti JRS, Obua C, Kukunda-Byobona C, Lanyero H, Byakika-Kibwika P, Bbosa GS, Lubega A, Ogwal-Okeng J, Ryan M, Waako PJ, Merry CMedicinal plants used by traditional medicine practitioners for the treatment of HIV/AIDS and related conditions in Uganda. J. Ethnopharmacol. . 2014; 130:43-53.

175. Moshi M, Otieno D, Mbabazi P, Weisheit A. Ethnomedicine of the Kagera Region, north western Tanzania. Part 2: the medicinal plants used in Katoro Ward, Bukoba District. J.Ethnobiol. Ethnomed. 2010; 6:19.

176. Mugisha MK, Asiimwe S, Namutebi A, Borg-Karlson A-K, Kakudidi EK. Ethnobotanical study of indigenous knowledge on medicinal and nutritious plants used to manage opportunistic infections associated with HIV/AIDS in western Uganda. J. Ethnopharmacol. 2014; 155:194-202.

177. Tchouya GRF, Souza A, Tchouankeu JC, Yala JF, Boukandou M, Foundikou H, Nguema Obiang GD, Boyom FF, Mabika Mabika R, Zeuko’o Menkem E, Ndinteh DT, Lebibi J. Ethnopharmacological surveys and pharmacological studies of plants used in traditional medicine in the treatment of HIV/AIDS opportunistic diseases in Gabon. J. Ethnopharmacol. 2015; 162:306-316.

178. Dibong SD, Mvogo Ottou PB, Vandi D, Ndjib RC, Tchamaha FM, Mpondo Mpondo E. Ethnobotanique des plantes médicinales anti hémorroïdaires des marchés et villages du Centre et du Littoral Cameroun. J. Appl. Biosci. 2015; 96:9072-9093.

179. Ouattara D. Contribution à l'inventaire des plantes médicinales significatives utilisées dans la région de Divo (sud forestier de la Côte-d'Ivoire) et à la diagnose du poivrier de Guinée : Xylopia aethiopica (Dunal) A. Rich. (Annonaceae). Thèse de Doctorat de l'Université de Cocody-Abidjan (Côte-d'Ivoire), UFR Biosciences, Laboratoire de Botanique; 2006. p 184. 